\title{
The Heidelberg Basin drilling project: Geophysical pre-site surveys
}

\author{
Hermann Buness, Gerald Gabriel \& Dietrich Ellwanger*)
}

\begin{abstract}
Currently, the Heidelberg Basin is under investigation by new cored research boreholes to enhance the understanding concerning the control on Pliocene and Quaternary sedimentation by (neo)tectonics and climate. The Heidelberg Basin is expected to serve as a key location for an improved correlation of parameters that characterise the climate evolution in North Europe and the Alpine region. The recovery of sediment successions of high temporal resolution that are complete with respect to the deposition of Pleistocene glacials and interglacials in superposition is of special importance. Prior to the new research boreholes in Viernheim and Heidelberg geophysical pre-site surveys were performed to identify borehole locations that best achieve these requirements. In the area of the Heidelberg Basin the strongest negative gravity anomaly of the entire Upper Rhine Graben is observed (apart from the Alps), hinting at anomalously thick sediment deposits. However, especially reflection seismic profiles contributed significantly to the decision about the borehole locations. In the city of Heidelberg for the first time, the depocentre of the Heidelberg Basin, as indicated by additional subsidence compared to its surroundings, was mapped. In this area, sediments dip towards the eastern margin of the Upper Rhine Graben. This is interpreted to represent a rollover structure related to the maximum subsidence of the Upper Rhine Graben in this region. At the Viernheim borehole location the seismic survey revealed several faults. Although these faults are mainly restricted to depths greater than $225 \mathrm{~m}$, the borehole location was finally adjusted with respect to this information.
\end{abstract}

\section{[ Das Bohrprojekt Heidelberger Becken: Geophysikalische Voruntersuchungen]}

Kurzfassung: Das Heidelberger Becken wird aktuell durch neue Kernbohrungen untersucht, um das Wissen hinsichtlich der Steuerung der pliozänen und quartären Sedimentation durch Klima und (Neo)Tektonik $\mathrm{zu}$ erweitern. Es wird erwartet, dass das Heidelberger Becken eine Schlüsselstelle für eine verbesserte Korrelation von Parametern darstellt, welche die Klimaentwicklung in Nordeuropa und im alpinen Raum charakterisieren. Besondere Bedeutung hat daher die Gewinnung von Sedimentsukzessionen hoher zeitlicher Auflösung, die im Hinblick auf die Ablagerung kalt- und warmzeitlicher pleistozäner Sedimente in Superposition möglichst vollständig sind. Im Vorfeld der neuen Kernbohrungen bei Viernheim und Heidelberg wurden geophysikalische Vorerkundungen durchgeführt, um Bohrlokationen zu identifizieren, die diesen Ansprüchen am besten genügen. Im Bereich Heidelberg wird die größte negative Schwereanomalie des gesamten Oberrheingrabens beobachtet (mit Ausnahme der Alpen), was auf ungewöhnlich mächtige Sedimentablagerungen hindeutet. Aber insbesondere reflexionsseismische Messungen haben zur Auswahl der Bohrpunkte beigetragen. Im Stadtbereich von Heidelberg ist zum ersten Mal das Depozentrum des Heidelberger Beckens kartiert worden, abgebildet durch eine zusätzliche Absenkung gegenüber der Umgebung. In diesem Gebiet fallen die Sedimente zum östlichen Grabenrand hin ein. Dies wird als 'Rollover' Struktur interpretiert, die in Verbindung mit der maximalen Subsidenz des Oberrheingrabens in diesem Bereich steht. An der Bohrlokation Viernheim konnten durch die Seis-

\footnotetext{
*Adresses of authors: H. Buness, Leibniz Institute for Applied Geophysics, Stilleweg 2, D-30655 Hannover, Germany. E-Mail: hermann.buness@liag-hannover.de; G. Gabriel, Leibniz Institute for Applied Geophysics, Stilleweg 2, 30655 Hannover, Germany. E-Mail: gerald.gabriel@liag-hannover.de; D. Ellwanger, Landesamt für Geologie, Rohstoffe und Bergbau im Regierungspräsidium Freiburg, Alberstraße 5, 79104 Freiburg im Breisgau, Germany. E-Mail: dietrich.ellwanger@rpf.bwl.de
} 
mik zahlreiche Störungen abgebildet werden. Obwohl diese im Wesentlichen auf Tiefenbereiche größer $225 \mathrm{~m}$ beschränkt sind, wurde der Bohransatzpunkt schließlich aufgrund dieser Informationen gewählt.

Keywords: Heidelberg Basin, depocentre, research borehole, reflection seismic, gravity

\section{Introduction}

The Heidelberg Basin is located in the eastern part of the Northern Upper Rhine Graben
(URG; Fig. 1), bordered by the dominating master fault of the URG to the east. The boundary fault is assumed to extend deep into the crust, by 15 - $24 \mathrm{~km}$ according to MAUTHE,

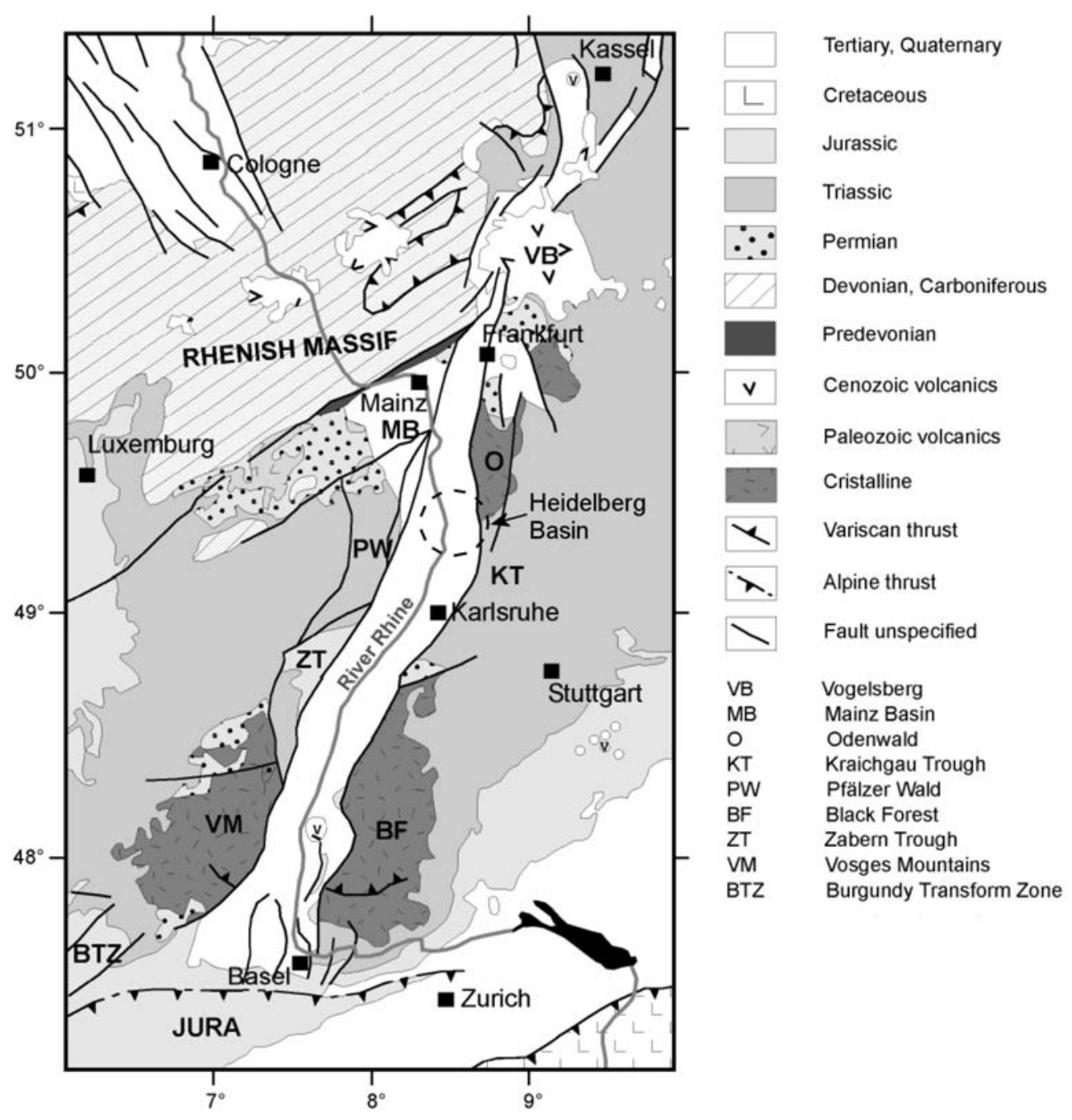

Fig. 1:Tectonic sketch map of the Upper Rhine Graben and its surroundings (after PETERS 2007). The approximate position of the Heidelberg Basin is marked by a dashed line.

Abb. 1: Tektonische Skizze des Oberrheingrabens und seiner Umgebung (nach Peters 2007). Die Lage des Heidelberger Beckens wird durch einen gestrichelten Kreis angedeutet. 
BRINK \& BURRI (1993). The sedimentary fill of the URG is characterised by synthetic and antithetic faults which strike parallel or subparallel to this boundary fault. The area of the Heidelberg Basin was subjected to continuous and strong subsidence since late Oligocene (SCHUMACHER 2002). Up to $1500 \mathrm{~m}$ sediments were deposited in early Miocene alone (comprising Cerethia, Corbicula, and Hydrobia beds). The thickest succession of Quaternary sediments can be found here (up to $350 \mathrm{~m}$ according to BARTZ 1974; Fig. 2, top).

The Heidelberg Basin constitutes therefore the most complete sediment archive of the whole URG. Sediments of different geosystems interfere with each other: the local system of the Neckar River (Odenwald), the regional Upper Rhine Graben-Highlands (Black Forest, Vosges) system, and the supra-regional Alps-Upper Rhine Graben system. Especially the distal deposits of the system Alps - Upper Rhine Graben are supposed to contain information about both the alpine and north European climate history, which can not be observed elsewhere (e.g. Ellwanger et al. 2005). The term Heidelberg Basin stands for the Miocene to Quaternary depocentre of the northern URG with an extent of some tens of $\mathrm{km}$. The term 'Heidelberger Loch', sometimes also found in literature, was introduced by SALOMON (1927) and denotes the locally, very delimited centre of subsidence around the city of Heidelberg.

The exploration of this sediment archive is the aim of two new research boreholes sponsored by the Leibniz Institute of Applied Geophysics (LIAG - former Leibniz Institute for Applied Geosciences, GGA-Institut) and the geological surveys of Baden-Württemberg (LGRB) and Hessen (HLUG) (Fig. 2, bottom). One of the boreholes was drilled exactly in the depocentre of the basin, close to the outlet of the Neckar River, from the Odenwald to the plain of the Upper Rhine Graben ('Heidelberg UniNord', Ellwanger et al. 2008). The other one was drilled in the geographic centre of the Heidelberg Basin about $17 \mathrm{~km}$ to the northwest, near the city of Viernheim (Hoselmann 2008). These two locations are complemented by two boreholes in Ludwigshafen that were drilled on the 'Parkinsel' island on the western margin of the basin (Fig. 2, bottom; WeIDENFELler \& KNIPPING 2008).

Prior to drilling these boreholes, a number of seismic profiles were carried out to facilitate a profound drilling design (Fig. 2; bottom). This included an estimation of depths for the geological targets, i.e. Pliocene and Pleistocene strata as well as the detection of possible fault zones. The latter point was important because the boreholes were to serve as a stratigraphic reference for the Quaternary sediment succession. Furthermore, high resolution seismic profiles in general are able to reveal tectonic and sedimentological events caused by the continued subsidence of the basin.

This article presents the results of the pre-site surveys. However, at the present stage, as there is not even a consistent and homogenous interpretation of all available borehole data, it is not possible to make conclusions about the basin dynamics (e.g. a seismostratigraphic interpretation). A more exhaustive analysis of the data could be done in the framework of a project, which was proposed to the German Research Foundation and is currently under evaluation.

\section{Geological setting and nomenclature}

Knowledge about the deeper subsurface of the URG is based mainly on seismic profiling and evaluation of boreholes of the oil and gas industry, which was quite intensively done in this area. According to MAUthe, BrinK \& BURRI (1993), about $5000 \mathrm{~km}$ seismic lines were recorded between 1970 and 1992. An extensive presentation of these activities is not possible due to the lack of corresponding publications. However, isobath maps derived from these data were published, e.g. for the Tertiary by DoEBL \& OlBrecht (1974) or for the Quaternary by BARTZ (1974).

Two deep-reaching reflection seismic profiles running across the southern and northern URG were carried out in 1988 in the framework of the DEKORP-ECORS Project (BRUN \& GUTSCHER 1992). The northern profile crosses the URG 


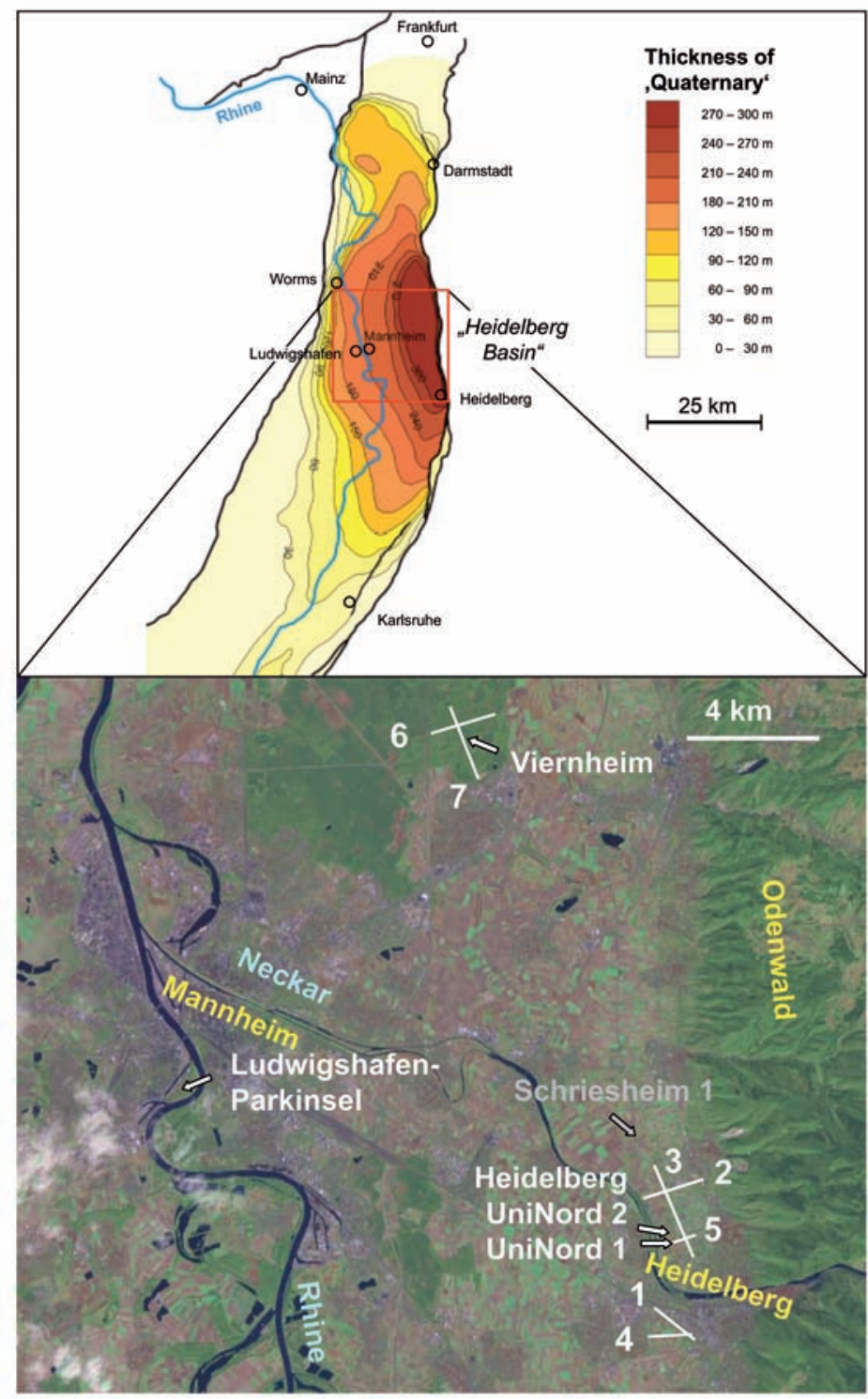

Fig. 2: Top: Thickness of 'Quaternary' in the northern part of the Upper Rhine Graben, adopted from BARTZ (1974, updated by HAIMBERGER, Hoppe \& SchäFER 2005). Bottom: Satellite view of the Heidelberg area (created with NASA World Wind, Vers. 1.3.2). White arrows: research boreholes Heidelberg UniNord (two boreholes in 2006 and 2008), Viernheim (2006), and Ludwigshafen-Parkinsel (two boreholes in 2002 and 2006); grey arrow: hydrocarbon well 'Schriesheim 1'. White lines: reflection seismic profiles 1-7 that are discussed in this paper.

Abb. 2: Oben: Mächtigkeiten des 'Quartär' im nördlichen Teil des Oberrheingrabens nach BARTZ (1974, aktualisiert durch HAIMBERGER, HopPE \& SCHÄFER 2005).

Unten: Satellitenaufnahme des Heidelberger Raums (erstellt mit NASA World Wind, Vers. 1.3.2). Weiße Pfeile: Forschungsbohrungen Heidelberg UniNord (zwei Bohrungen in 2006 und 2008), Viernheim (2006) und Ludwigshafen-Parkinsel (zwei Bohrungen in 2002 und 2006); grauer Pfeil: Kohlenwasserstoffbohrung 'Schriesheim 1'. Weiße Linien: reflexionsseismische Profile 1-7, die in diesem Artikel diskutiert werden. 
about $20 \mathrm{~km}$ north of Heidelberg. The varying reflector signature of the lower crust images the asymmetric structure of the URG. The largest Tertiary sediment thickness of $3400 \mathrm{~m}$ is observed close to the eastern rim of the graben, it reduces stepwise to $300 \mathrm{~m}$ below the western border. However, depths corresponding to the Quaternary, the Pliocene, and down to the middle Miocene units are poorly resolved.

The interaction between tectonic and sedimentation in the northern URG was investigated by DERER by means of sequence stratigraphy (Derer 2003, Derer et al. 2003, Derer, SchuMACHER \& SCHÄFER 2005), who found the area to be divided into two halfgrabens with opposing tilt directions by a transfer zone. The study was based on seismic profiles and geophysical borehole measurements made by the oil and gas industry. Seismic facies were assigned to several lithostratigraphic units from Eocene to the upper Miocene.

About $190 \mathrm{~km}$ of industrial seismic lines where shot between 1981 und 1993 in the Heidelberg Basin. However, these lines do not extend to the depocentre of the Heidelberg Basin ('Heidelberger Loch'). Furthermore, only little information about the structure of Plio-Pleistocene sediments can be derived from the hydrocarbon seismic lines, because these focused only on storage or sealing horizons, and hence deep structures. The existing gap in the reflection seismic data, near to the city of Heidelberg, can be partly filled by information from boreholes related to hydrogeological investigations. In the Heidelberg area two flush boreholes are available that reveal large thickness of Quaternary sediments: the $350 \mathrm{~m}$ deep Entensee borehole from 1973 (CONRADS \& SCHNEIDER 1977), about $1 \mathrm{~km}$ north, and the $1022 \mathrm{~m}$ deep Radium-Sol Therme borehole from 1918 (SALOMON 1927), about $1 \mathrm{~km}$ south of the new borehole Heidelberg UniNord 1 (Fig. 3).

Interpretation of these two boreholes is controversially discussed. The main problem here are the confusing definitions and applications of the terms Quaternary and Pliocene (and some other stratigraphic terms) in publications, reports and archives related to the URG. The most frequently applied 'traditional' definition relates 'Quaternary' to the onset of alpine sediments, i.e. to a change in sediment provenance. 'Pliocene' sediments come from local sediment sources, e.g. Black Forest, Vosges, and Odenwald; 'Quaternary' sediments include or correlate with sediments of alpine origin. This change of provenance is, of course, a matter of lithostratigraphy, although chronostratigraphic terms are used.

This different use of the term 'Quaternary' is illustrated by the controversial interpretations of the Radium-Sol Therme borehole by SAlomon (1927), BARTz (1951) and FEzer (1997). SAlOMON and BARTZ suggest depths of ' $382 \mathrm{~m}$ ' and 'almost $400 \mathrm{~m}$ ', both referring to the lithostratigraphic version of 'Quaternary'; FEZER suggests a depth of $650 \mathrm{~m}$ which is based upon a calculation of sedimentation rates i.e. he applies the term Quaternary in its proper chronostratigraphic sense.

The aim of this paper is not to solve problems of stratigraphic nomenclature but report seismic and gravimetric activities prior to the new drilling activities. Our references are the old data (publications, reports, and archive data) which are, at this state, not re-interpreted but used as they are. Stratigraphic terms are set in quotation marks where we feel the authors use the lithostratigraphic version (e.g. 'Quaternary'), and without quotation marks when used as chronostratigraphic term (e.g. Quaternary).

A reflection seismic profile that focused especially on the Quaternary deposits was published by Haimberger, Hoppe \& Schäfer (2005). This river seismic profile - recorded along the Rhine River between Mainz and Mannheim, and parts of the Neckar River over a length of $150 \mathrm{~km}$ in total - revealed high-resolution information which was able to define the base of 'Pleistocene' sediments mainly north of Mannheim. Maximum thickness of 'Pleistocene' was found in the area of Mannheim and confirmed the map published by BARTZ (1974; Fig. 2). This map images an increase of 'Pleistocene' sediment thickness towards the eastern boundary fault of the Upper Rhine Graben, where it amounts to more than $350 \mathrm{~m}$. 


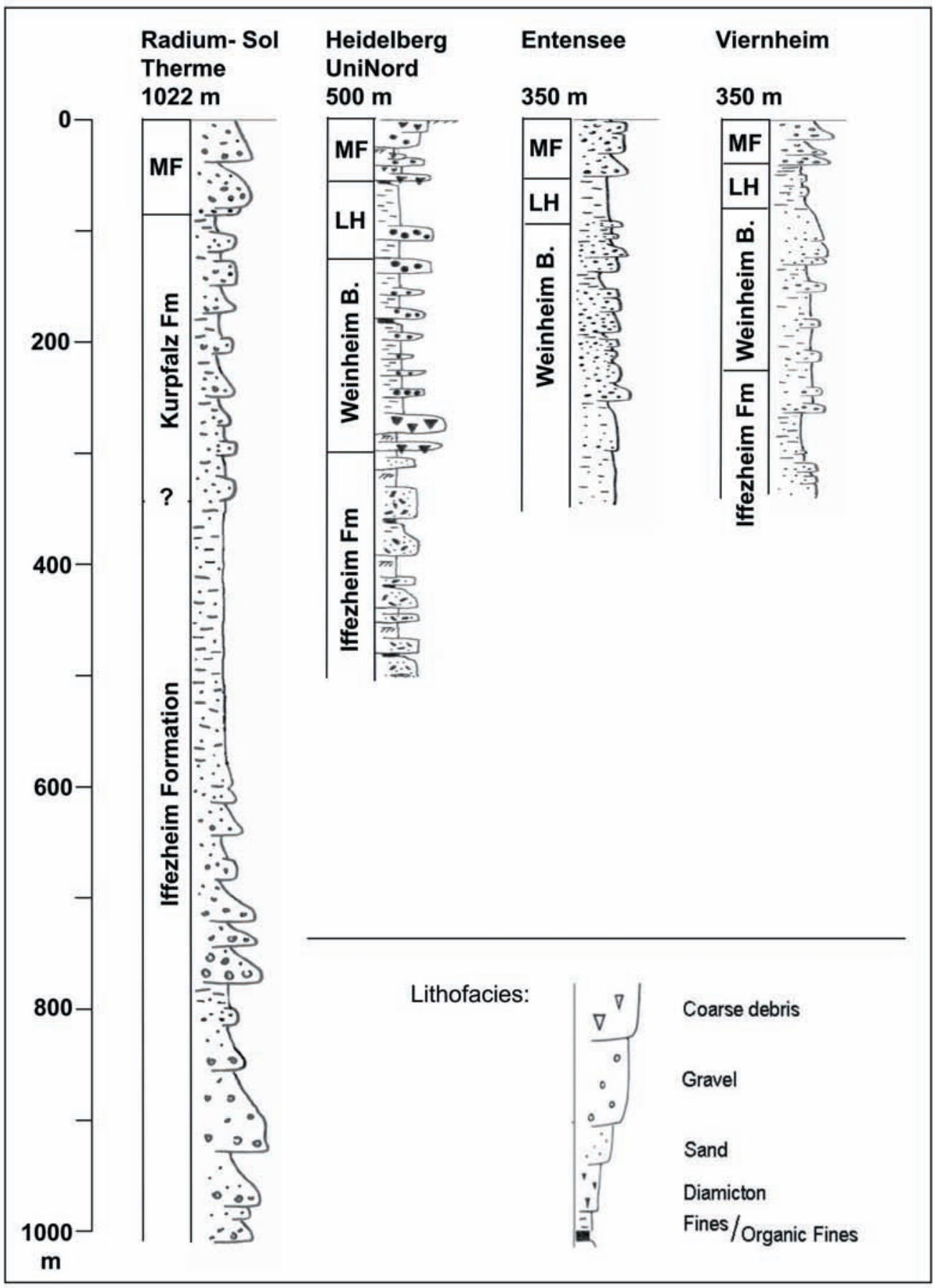

Fig. 3: Lithofacies logs from four boreholes in the Heidelberg Basin (MF: Mannheim-Formation, LH Ladenburg-Horizon).

Abb. 3: Lithofazieslogs von vier Bohrungen im Heidelberger Becken (MF Mannheim-Formation, LH Ladenburg-Horizont). 
Table 1: Different classifications of Plio-Pleistocene sediments, as used in the Upper Rhine Graben. The terms 'Altquartär' and 'Pliocene' (senso Bartz) are defined by lithofacies, rather than a strict geochronological classification.

Tab. 1: Gegenüberstellung verschiedener Einteilungen der plio-/pleistozänen Sedimente für den Oberrheingraben. Die Begriffe 'Altquartär' und 'Pliozän' (nach Bartz) definieren eher Sedimenttypen, denn eine strikte geochronologische Einordnung.

\begin{tabular}{|c|c|c|c|c|}
\hline \multicolumn{2}{|c|}{$\begin{array}{c}\text { Baden-Württemberg } \\
\text { Symbolschlüssel Geologie } \\
\text { Baden-Württemberg }\end{array}$} & $\begin{array}{c}\text { Rheinland-Pfalz } \\
\text { Weidenfeller \& Kärcher } 2008 \\
\text { Weidenfeller \& Knipping } 2008\end{array}$ & Hessen & Bartz 1982 \\
\hline & & & $\begin{array}{c}\text { Aeolian sand (Pleistocene to } \\
\text { Holocene) }\end{array}$ & \\
\hline \multirow{2}{*}{\multicolumn{2}{|c|}{ Mannheim-Formation }} & \multirow[t]{2}{*}{ Upper gravel layer (OKL) } & Sand-gravel layers & Oberes Kieslager (OKL) \\
\hline & & & Neckar dominated, less alpine & contains coarse material (alpine and local) \\
\hline \multirow{10}{*}{ 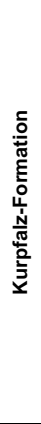 } & \multirow[t]{2}{*}{ Ladenburg Horizon } & \multirow[t]{2}{*}{ Upper interlayer $(\mathrm{OZH})$} & Interlayer & Obere Zwischenschicht (OZ) \\
\hline & & & predominant fine-clastic sediments & only fine material \\
\hline & \multirow{8}{*}{ Weinheim Beds } & \multirow[t]{2}{*}{ Middle sand-gravel layer } & \multirow[t]{2}{*}{ Alternation of } & Mittleres Kieslager (MKL) \\
\hline & & & & contains coarse material \\
\hline & & \multirow[t]{2}{*}{ Lower interlayer (UZH) } & \multirow{3}{*}{$\begin{array}{l}\text { sand-(gravel) layers } \\
\text { frequently in "Rhenish } \\
\text { Facies" and }\end{array}$} & Untere Zwischenschicht (UZ) \\
\hline & & & & only fine material \\
\hline & & \multirow{4}{*}{ Lower sand-silt layer } & & Unteres Kieslager (UKL) \\
\hline & & & \multirow[t]{2}{*}{ fine-clastic interlayers } & contains coarse material \\
\hline & & & & 'Altquartär 1 and 2' (AQ1 and AQ2) \\
\hline & & & Rhine (alpine) material, less Neckar & transition unit, contains the lowermost alpine material \\
\hline \multicolumn{5}{|c|}{ major change of provenance } \\
\hline \multirow{2}{*}{\multicolumn{2}{|c|}{ Iffezheim-Formation }} & \multirow[t]{2}{*}{ Clay-silt-sand-layer } & Clay-silt- and sand-layers & 'Pliocene I-III' \\
\hline & & & material of local provenance & material of local provenance \\
\hline
\end{tabular}

The interpretation of the river seismic data revealed well the alternating sequence of coarsegrained layers (aquifers, so called 'Kieslager') and fine-grained layers (aquitards, so called 'Zwischenhorizonte') typical of the Heidelberg Basin. This hydrostratigraphic classification (Table 1) is often used in the northern part of the Upper Rhine Graben due to a lack of geochronological data concerning Pliocene and Pleistocene strata. It is based on a macroscopic description of the sediments, their colours and carbonate content, and as complementary information on gamma logs, where available. The hydrostratigraphy was broadly introduced by BARTZ (1982). It is presently much used in hydrogeology (HGK 1999) and was last updated by Weidenfeller \& KÄrCher (2008). On a larger scale it distinguishes between three coarse-grained layers separated by two fine-grained layers, which are regionally distributed. In the system after BARTz (1982) this alternating succession is separated from the underlying provenance change by another unit called 'Altquartär' ('Early Quaternary'). This term again is used as description of a sediment type rather than a stringent chronostratigraphic classification. In more recent publications and reports, the lowest coarse-grained bed is defined as Early Quaternary (WeIDENFELLER \& KÄrCHER 2008). The thickness of each layer is quite variable in a lateral direction. Locally, additional fine- or coarse-grained layers of smaller extent can be intercalated. The occurrence of fine-grained sediments was traditionally related to interglacial periods, and the occurrence of coarse-grained layers to glacial periods (BARTZ 1982).

One of the aims of this drilling project is to correlate the before mentioned hydrostratigra- 


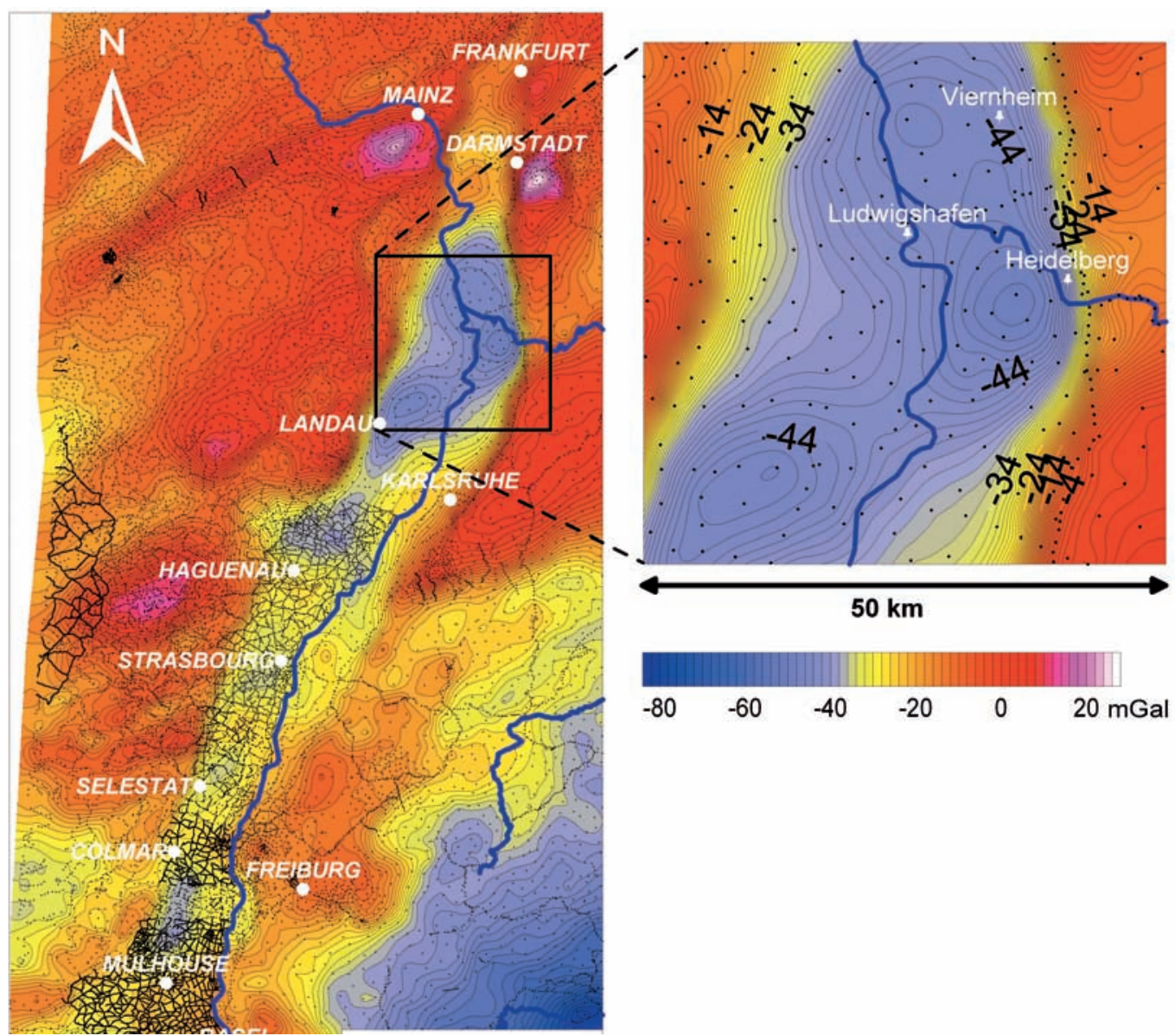

Fig. 4: Bouguer map of the entire Upper Rhine Graben (after RotsteIN et al. 2006) and the Heidelberg area in more detail, with the three research borehole locations Ludwigshafen-Parkinsel, Viernheim, and Heidelberg. Contour intervals: $2 \mathrm{mGal}$ (regional map) and $1 \mathrm{mGal}$ (local map); black dots: gravity stations.

Abb. 4: Bouguer-Karte des gesamten Oberrheingrabens (nach RotsTeIN et al. 2006) und des Heidelberger Raums im Detail mit den drei Lokationen der Forschungsbohrungen Ludwigshafen-Parkinsel, Viernheim und Heidelberg. Isolinienabstand $2 \mathrm{mGal}$ (regionale Karte) und $1 \mathrm{mGal}$ (lokale Karte); schwarze Punkte: gravimetrische Messpunkte.

phy with the lithostratigraphy of the southern part of the Upper Rhine Graben (SymbolSchlüssel Geologie Baden-Württemberg). The upper gravel layer can be quite well correlated with the Mannheim Formation, and the upper interlayer (fine-grained layer) with the Ladenburg Horizon. The succession of the middle sand-gravel layer and lower sand-silt layer and the interlayer in between is only roughly equivalent to the Weinheim Beds (Table 1).

\section{Gravimetry}

Generally, gravity anomaly data is expected to reflect a first-order pattern of the shape of the Heidelberg Basin, especially varying thickness of (unconsolidated) Pliocene/Pleistocene sediments. The mean density of Plio-Pleistocene sediments should be reduced compared to Tertiary or even older and more compacted sediments. Therefore the anomalous thick sedimentary fill of the Heidelberg Basin should cause a 


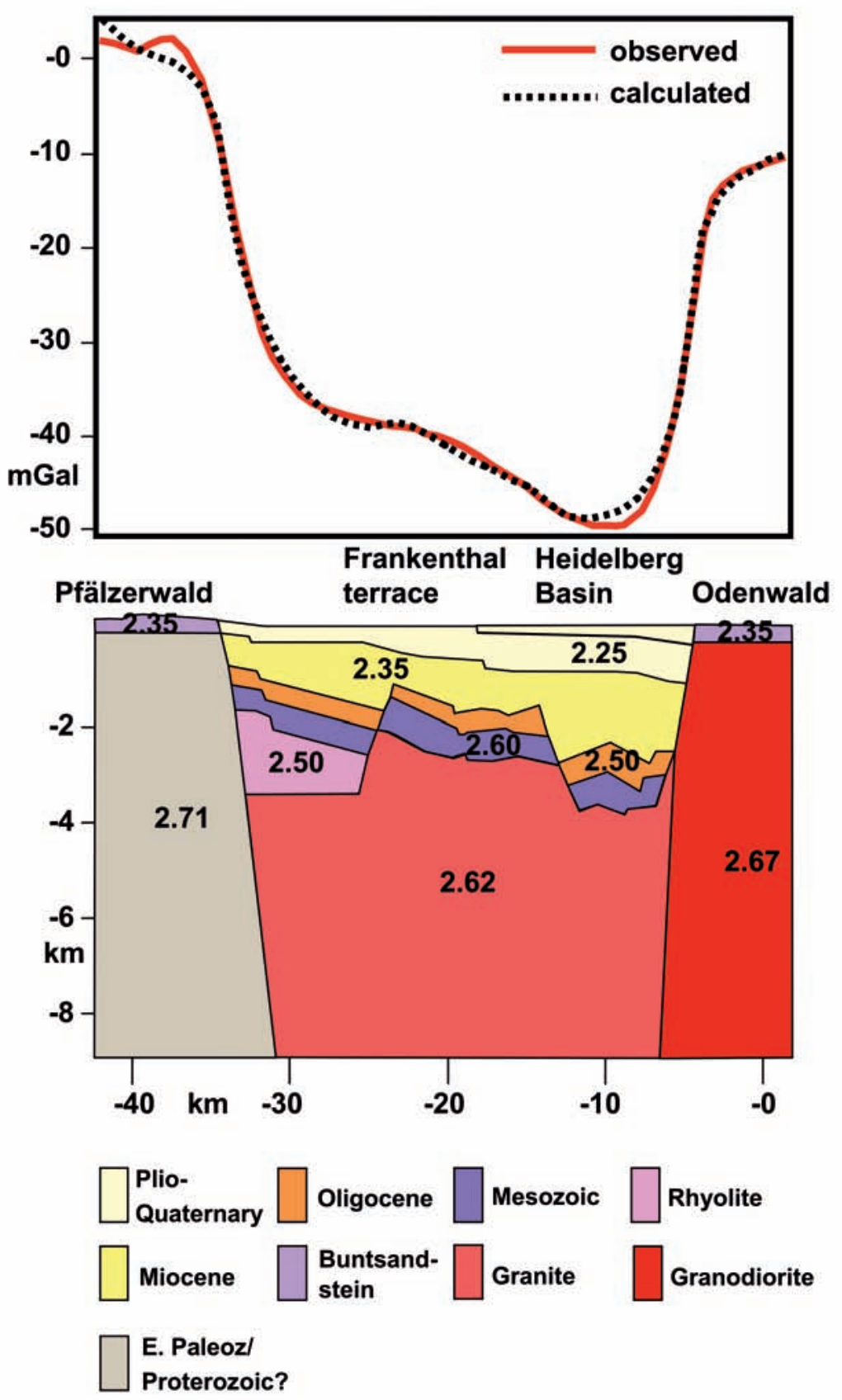

Fig. 5: 2-D gravity profile across the Rhine Graben in the Heidelberg area. Although the regional gravity field correlates well with sediment thickness, additional density contrasts in the basement are required to explain the observed anomalies in the western part.

Abb. 5: Gravimetrisches 2-D Profil über den Rheingraben im Raum Heidelberg. Wenngleich das regionale Schwerefeld gut mit den Sedimentmächtigkeiten korreliert, müssen Dichtekontraste im Basement angenommen werden, um die beobachteten Anomalien des westlichsten Profilabschnitts zu erklären. 
negative gravity anomaly that can be related to the the extent of the basin and its depth. But in fact the situation is more complicated.

\section{Gravity data}

Gravity data for the Upper Rhine Graben is available from several sources. RotsteIn et al. (2006) have compiled the most recent Bouguer gravity map of the Upper Rhine Graben comprising all the available data from France and Germany (Fig. 4; regional map). This map is based on about 33.000 Bouguer gravity values. About one third of the data was provided by the Leibniz Institute for Applied Geophysics covering the German part of the Rhine Graben. This dataset consists of data available from the Geophysikalische Reichsaufnahme, but also some local surveys. The French data is mainly based on two data sources, which are themselves compilations of numerous surveys. The first dataset - about fifty percent of the French data - was provided by the Bureau de Recherches Géologiques et Minières, the second one by Mines de Potasse d'Alsace. A complete Bouguer anomaly was recalculated for the entire new dataset, using a density of $2670 \mathrm{~kg} / \mathrm{m}^{3}$ and considering newly-calculated terrain reductions. The distribution of the gravity stations is strongly inhomogeneous; their spatial coverage varies significantly from about 0,25 stations $/ \mathrm{km}^{2}$ in some parts of the Vosges and Black Forest and 40 stations $/ \mathrm{km}^{2}$ in some parts of the graben itself. Note, the complete Bouguer map is based on a calculated grid of $1 \mathrm{~km}$.

The area of the Heidelberg Basin (Fig. 4; local map) is characterised by the strongest gravity anomaly of the entire Upper Rhine Graben (apart from the most southern part where the regional trend is strongly affected by the Alps). It is in the order of -40 to $-50 \mathrm{mGal}$, with the absolute minimum close to the outlet of the Neckar River, from the Odenwald in the plain of the Upper Rhine Graben (Fig. 4).

\section{Preliminary Interpretation}

When interpreting the anomaly apparently related to the sediment fill of the Heidelberg Basin some general knowledge regarding the source of gravity anomalies in the Upper Rhine Graben has to be considered. Rotstein et al. (2006) performed some two-dimensional calculations along profiles approximately perpendicular to the strike of the graben. Although these profiles were restricted to the southern part of the graben and a two-dimensional approach is not suitable to investigate the complex graben geology in great detail, their general result showed, that the gravity anomalies are not only caused by the sediment fill of the graben, but that they are also strongly affected by density inhomogeneities in the crystalline basement. One of the profiles south of Karlsruhe revealed increasing sediment thicknesses from west to east accompanied by increasing Bouguer gravity values - the structure of the sediments was well constrained by reflection seismic data and drilling information. Therefore, for this profile the gravity effect of the sediments must be overcompensated by density contrasts in the basement.

Density of the basement must be assumed to be of high lateral variation as that of rocks of the adjacent graben shoulders is. Therefore, some impact on the Bouguer anomalies observed in the area of the Heidelberg Basin must also be assumed. A preliminary 2-D profile which crosses the Rhine Graben close to Heidelberg is shown in Fig. 5. Although the structural resolution of the sediments is rather low, the necessity to introduce at least lateral density contrasts at the western and eastern boundary faults and within the most western part of the basement is obvious.

Nevertheless, the sediments of the Heidelberg Basin will undoubtedly contribute to the negative gravity anomalies observed in this region. Confirming the map of 'Quaternary' thickness in the Upper Rhine Graben published by BARTZ (1974), the new reflection seismic profiles recorded in the framework of the pre-site surveys reveal anomalously thick Neogene sediments. From the downhole logging experiments conducted in the Heidelberg Drilling Project, low densities between $2000 \mathrm{~kg} / \mathrm{m}^{3}$ and $2300 \mathrm{~kg} / \mathrm{m}^{3}$ can be estimated for the Pleistocene sediments (Hunze \& WoniK 2008), whereas Tertiary sedi- 


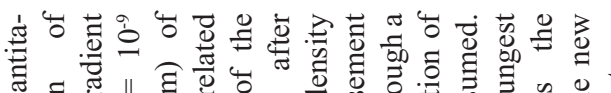

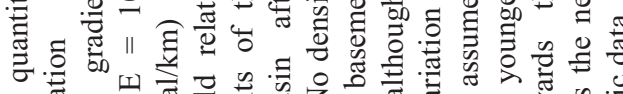

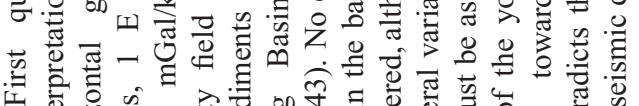

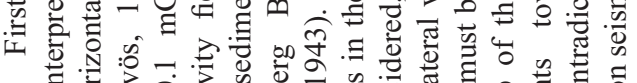
o.

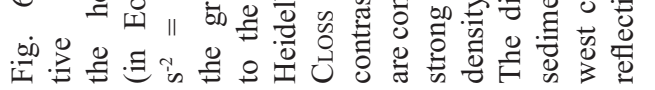
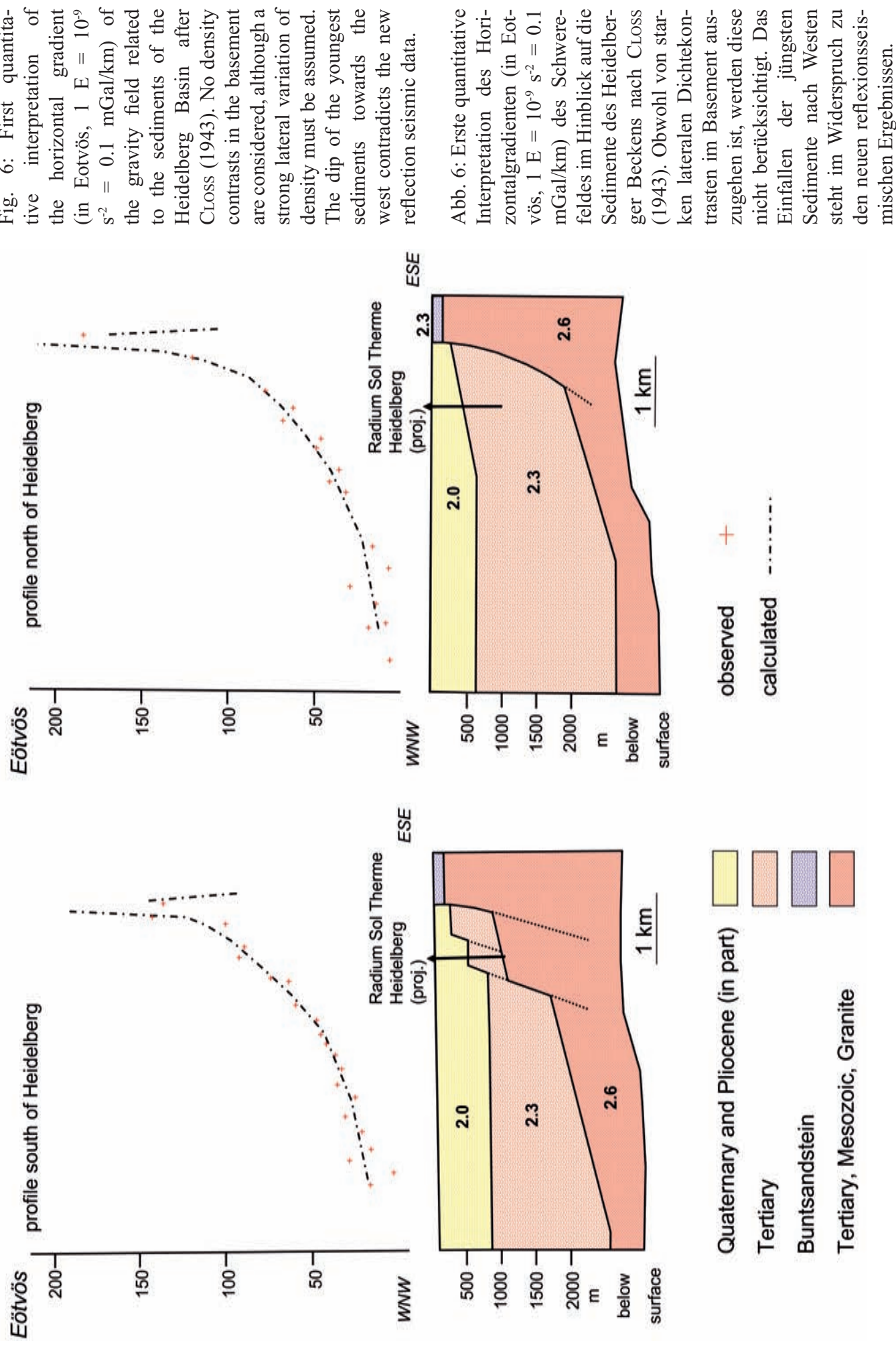
ments in the Upper Rhine Graben are known to have densities between $2350-2450 \mathrm{~kg} / \mathrm{m}^{3}$, strongly depending on the amount of evaporates in the Early Oligocene strata, at least in the southern part of the graben (RoTSTEIN et al. 2006).

Interpreting the observed gravity anomalies only in terms of varying sediment thickness, two main centres of deposition can be distinguished: one between Heidelberg and the Rhine River, and the second northeast of Landau (Fig. 4). Considering the information about Base 'Quaternary' (Fig. 2), the anomaly close to Landau is not related to anomalously thick Quaternary deposits. The source of this anomaly must be assumed to be at greater depth. This source can be located either in the older sediments, e.g. thick deposits of Early Miocene age in agreement with Schumacher (2002), or in the basement, e.g. an extension of units that outcrop in the northern Odenwald today, to the southwest. Only the large negative gravity anomaly east of the Rhine River can be discussed in terms of varying thickness of Quaternary sediments, even though this interpretation is ambiguous. This anomaly is related, at least to some extent, to the 'Heidelberger Loch'. The Ludwigshafen boreholes are located on the western margin of this basin structure; the Heidelberg UniNord borehole close to the absolute gravity minimum. With respect to the map of 'Quaternary' sediments (BARTZ 1974, improved by Haimberger, Hoppe \& Schäfer 2005), the Heidelberg Basin extends further southwards, towards Karlsruhe. This extension cannot be traced unequivocally in the gravity map, where north and west of Karlsruhe a relative gravity high occurs. The contour lines delimiting this relative gravity high from the more distinct gravity low to the north strike nearly W-E, which is not in accordance with the map of Base 'Quaternary'. But these observations correspond well with the quantitative interpretation of the gravity anomalies south of Karlsruhe discussed previously and presented by Rotstein et al. (2006). High density Early Palaeozoic and Proterozoic rocks in the basement are suggested as source for this anomaly compensating the gravity effect of sediments. First quantitative interpretations of the gravity field of the Heidelberg Basin were published by Closs (1943). Based on torsion balance data, models were derived that explain the observed horizontal gradient (in Eotvös, $1 \mathrm{E}=10^{-9} \mathrm{~s}^{-2}$ $=0.1 \mathrm{mGal} / \mathrm{km}$ ) running from the Odenwald in the east about $5 \mathrm{~km}$ into the Upper Rhine Graben in the west (Fig. 6). Therefore, only the local situation at the eastern graben boundary fault was investigated. The thickness of Pleistocene and youngest Plicocene sediments is estimated to be $\sim 500 \mathrm{~m}$ at the Heidelberg UniNord location. Furthermore in CLOss's model the uppermost sediment unit dips with about $45^{\circ}$ towards west - strongly contradicting the result of the new reflection seismic surveys. Density contrasts in the crystalline basement of the URG in this region were not taken into account, although from the adjacent Odenwald a large variety of alkaline (high density) and acidic (lower density) rocks are known.

\section{Seismic survey and data processing}

Seismic measurements in urban areas often encounter considerable difficulties. Restrictions exist for seismic sources (only low-energy seismic sources, services lines, endangerment of supply lines, services pipes, traffic restrictions, etc.) as well as for the recording side (sealing of the surface, enhanced noise level, etc.). The design of seismic profiles is therefore more often dictated by logistics than by geological reasoning.

At the start of the project a borehole location in Heidelberg was proposed at the abandoned freight depot south of the Neckar River (Fig. 7). A $1.5 \mathrm{~km}$ long profile (profile 1) was therefore measured, that showed strong inclinations of deep reflectors. To check the true inclination of the reflectors, the data were supplemented by a second profile later on (profile 4). The profiles could not be connected to existing industry profiles (the next one being about $1.5 \mathrm{~km}$ apart to the SW), but the interpretation could be done by comparison of reflection patterns. The borehole Radium Sol Therme could barely be 


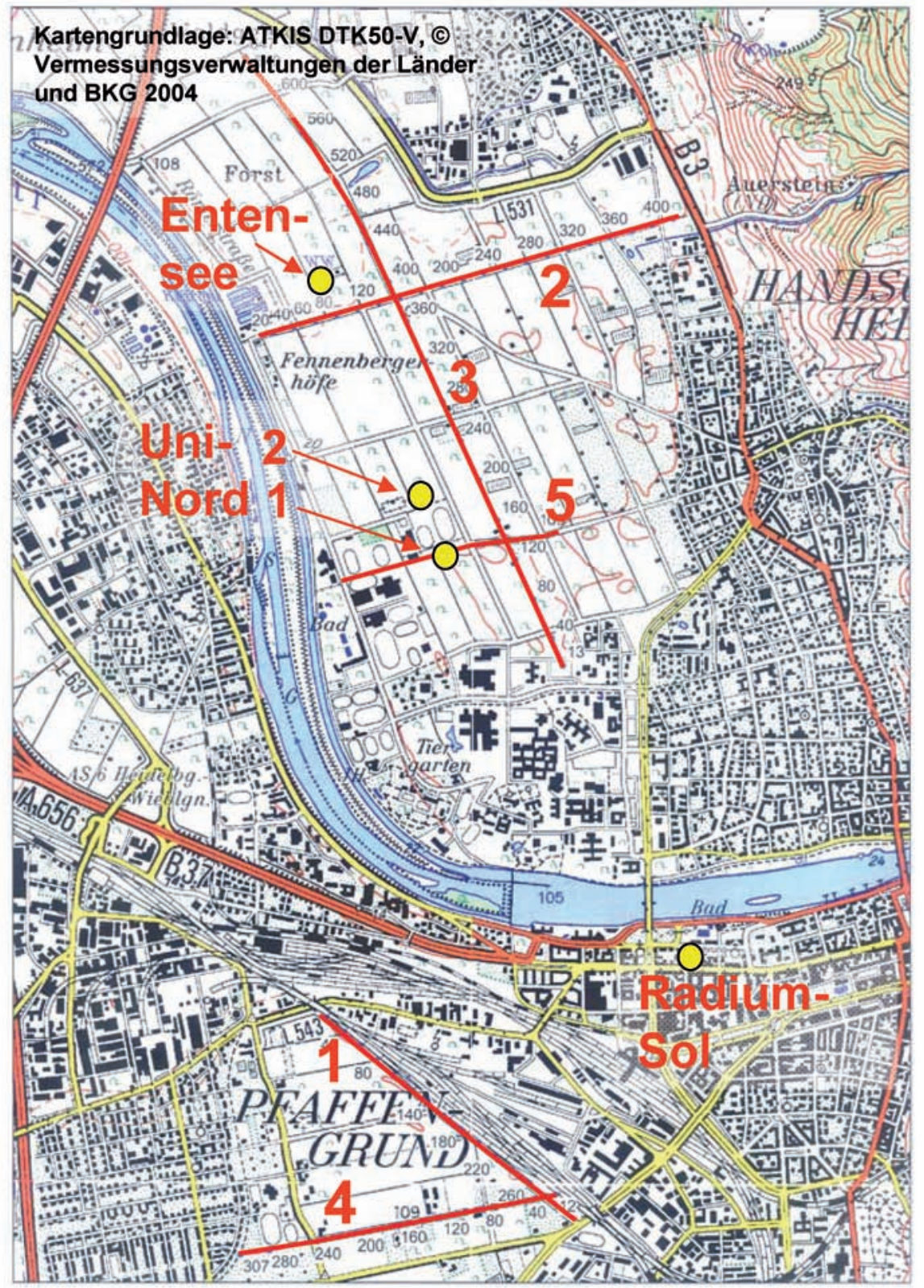

Fig. 7: Seismic reflection profiles (red lines) measured in Heidelberg. Yellow points indicate boreholes mentioned in this paper.

Abb. 7: In Heidelberg aufgezeichnete reflexionsseismische Profile (rote Linien). Gelbe Punkte markieren die in diesem Artikel genannten Bohrungen. 


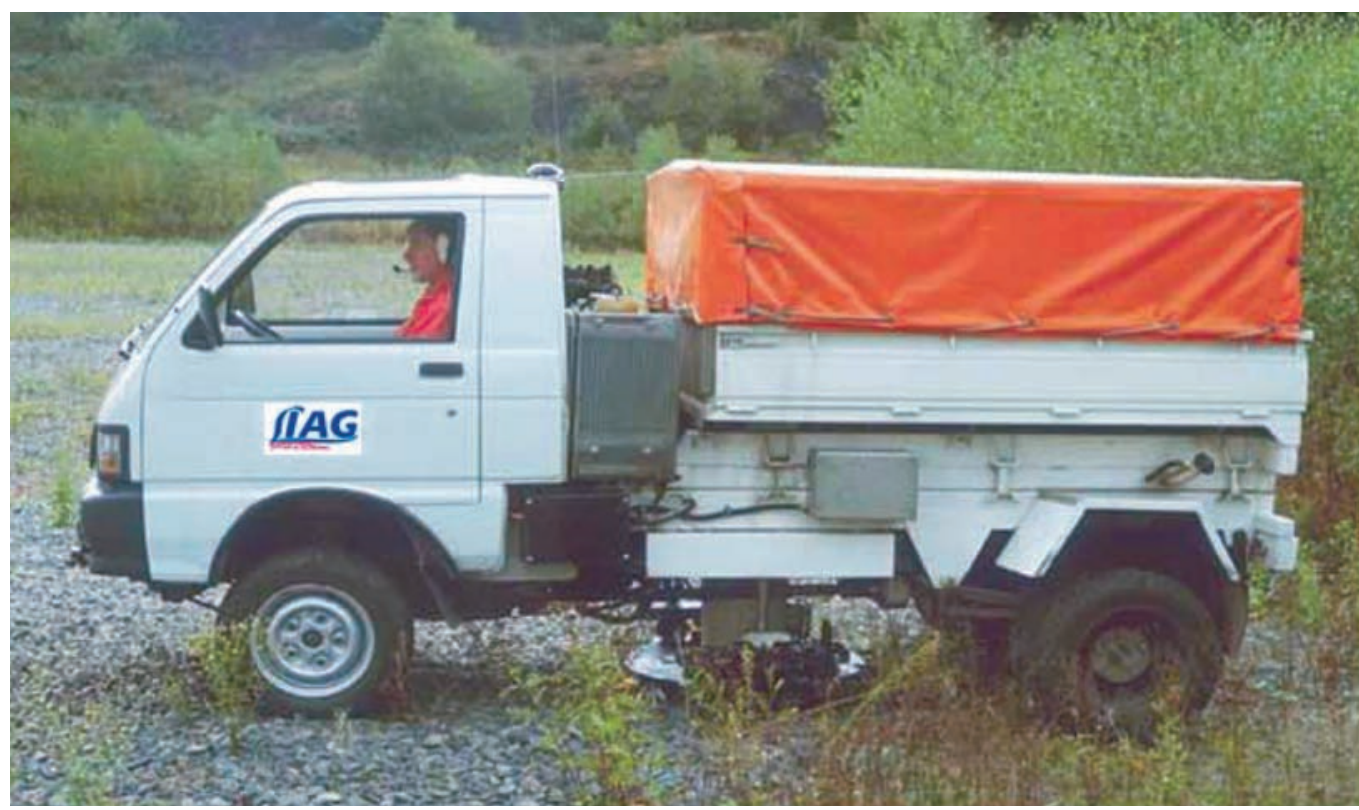

Fig. 8: Seismic hydraulic vibrator, constructed for near surface high resolution profiling.

Abb. 8: Seismischer Hydraulikvibrator, der für hoch auflösende oberflächennahe Messungen entwickelt wurde.

used for interpretation due to its controversial interpretation. In addition, data quality suffered due to extreme electromagnetic disturbances of $162 / 3 \mathrm{~Hz}$ and its multiples up to $500 \mathrm{~Hz}$.

North of the Neckar River the building density is lower, improving the conditions for seismic measurements. First, a profile perpendicular to the general trend of faults was shot (profile 2). After some encouraging results, a longer north - south trending profile (profile 3) was registered. However, continuation to the exploration

Table 2: Recording parameters used in the reflection seismic surveys.

Tab. 2: Aufnahmeparameter der reflexionsseismischen Messungen.

\begin{tabular}{l|ll}
\hline & Profiles 1-4 & profiles 5-7 \\
\hline Seismic source & GGA-vibrator MHV 2.7 & GGA-vibrator MHV 2.7 \\
Sweep & $16 \mathrm{~s}$ linear, 30-180 Hz & $16 \mathrm{~s}$ linear, 30-180 Hz \\
Recording length & $20 \mathrm{~s}$ & $20 \mathrm{~s}$ \\
Source/recording point distance & $10 \mathrm{~m} / 10 \mathrm{~m}$ & $5 \mathrm{~m} / 5 \mathrm{~m}$ \\
Reflexion point distance & $5 \mathrm{~m}$ & $2,5 \mathrm{~m}$ \\
Geophone type & SM4, 20 Hz & SM4, 20 Hz \\
Group length/geophones in group & $5 / 6$ &,- 1 \\
Spread & fixed spread (p. 1, 4) end on (p. 2,3) & end on \\
Recording instrument & Geometrics (StrataVisor or Geodes) & Geometrics (Geodes) \\
Recording mode & unstacked, uncorrelated & unstacked, uncorrelated \\
Number of channels & $72(\mathrm{p} .1,2), 120$ (p. 3, 4) & 120 \\
Vertical stacks & 4 & 2 \\
Samplerate & $1 \mathrm{~ms}$ & $1 \mathrm{~ms}$ \\
\hline
\end{tabular}


borehole 'Schriesheim', about $1 \mathrm{~km}$ further north (Fig. 2), could not be established. After fixing the location of the research borehole 'Heidelberg UniNord 1', another short profile (profile 5) was shot to check for possible fault zones. In this area signal quality was degraded by waves originated from service pipes (called 'pipe waves' for simplicity further on). These are especially visible on profile 2 and profile 5 . The two profiles at the Viernheim location (profiles 6 and 7 in Fig. 2) were laid out perpendicular to each other, with the proposed position of the research drilling at their crossing point. The profiles were surveyed in a forested area without further problems.

All profiles were shot by a small hydraulic vibrator (Fig. 8), which yields a maximum peak force of $30 \mathrm{kN}$ and a frequency range of $20-500 \mathrm{~Hz}$ (for recording parameters cp. Table 2). This vibrator was developed especially for high-resolution shallow profiling (Buness \& Wiederhold 1999, VAN DER VeEN et al. 2000). It is very appropriate for use in an urban environment, due to its relatively low impact on the surface, compared to e.g. weight dropping or other impulsive sources. Data were processed using a commercial processing system (ProMAX, Landmark Corp.). Processing steps are listed in Table 3 , details regarding the single steps are discussed e.g. in YILMAZ (2001). In addition, to the processing steps listed in Table 3, waves in profiles 2 and 5 were suppressed by trace-mixing algorithms. Trace mixing, although a very simple algorithm, proved to be most effective of a variety of other algorithms, including spatial 2D filters, $\mathrm{f}-\mathrm{k}$ based filters and eigenvector filtering. However, the incoherency of this kind of noise prevents elimination without damaging the reflection signal.

The velocity fields for finite-difference migration and for the subsequent depth conversion were derived from the smoothed stacking velocity fields. The deviations from the velocities derived by the VSP (vertical seismic profile) measurements carried out in the UniNord 1 borehole down to a depth of $180 \mathrm{~m}$ turned out to be very small, hence the former were kept during later processing. The structure of the uppermost low velocity layer down to a depth of $20 \mathrm{~m}$ could not be determined adequately, causing some uncertainty about the overall depth level of the profiles. As a consequence the depth level was calibrated using the VSP reflections, which have a known depth. A reference level of $100 \mathrm{~m}$ a.s.l. was chosen for all profiles.

Table 3: Typical data processing flow

Tab. 3: Typischer Prozessingsablauf

1. correlation with field sweep

2. quality control

3. vertical stack

4. automatic gain control $300 \mathrm{~ms}$

5. deconvolution (spiking, zero phase, $30 \mathrm{~ms}$ operator)

6. bandpass $30-180 \mathrm{~Hz}, 24 \mathrm{db} /$ oct.

7. surgical mute of surface waves and shear waves

8. attenuation of air-coupled waves

9. refraction static to floating datum

10. velocity analysis and iterative application of residual static (initial step with lowpass $90 \mathrm{~Hz}$ )

11. stack to final datum $(100 \mathrm{~m})$

12. FX deconvolution $(60-180 \mathrm{~Hz})$

13. automatic gain control $500 \mathrm{~ms}$

14. FD migration

15. depth conversion

\section{Results}

\section{Heidelberg - the region north of the Neckar River}

The profile which is best tied to an existing deep borehole is the north-south trending profile 3 in the area north of the Neckar River: the Schriesheim borehole is located about $1 \mathrm{~km}$ further north (Fig. 2). Although no direct connection between the newer seismic line and the borehole exists, the geological structures can be controlled by hydrocarbon seismic lines. Both, E-W and N-S trending profiles that cross the Schriesheim borehole are available. 


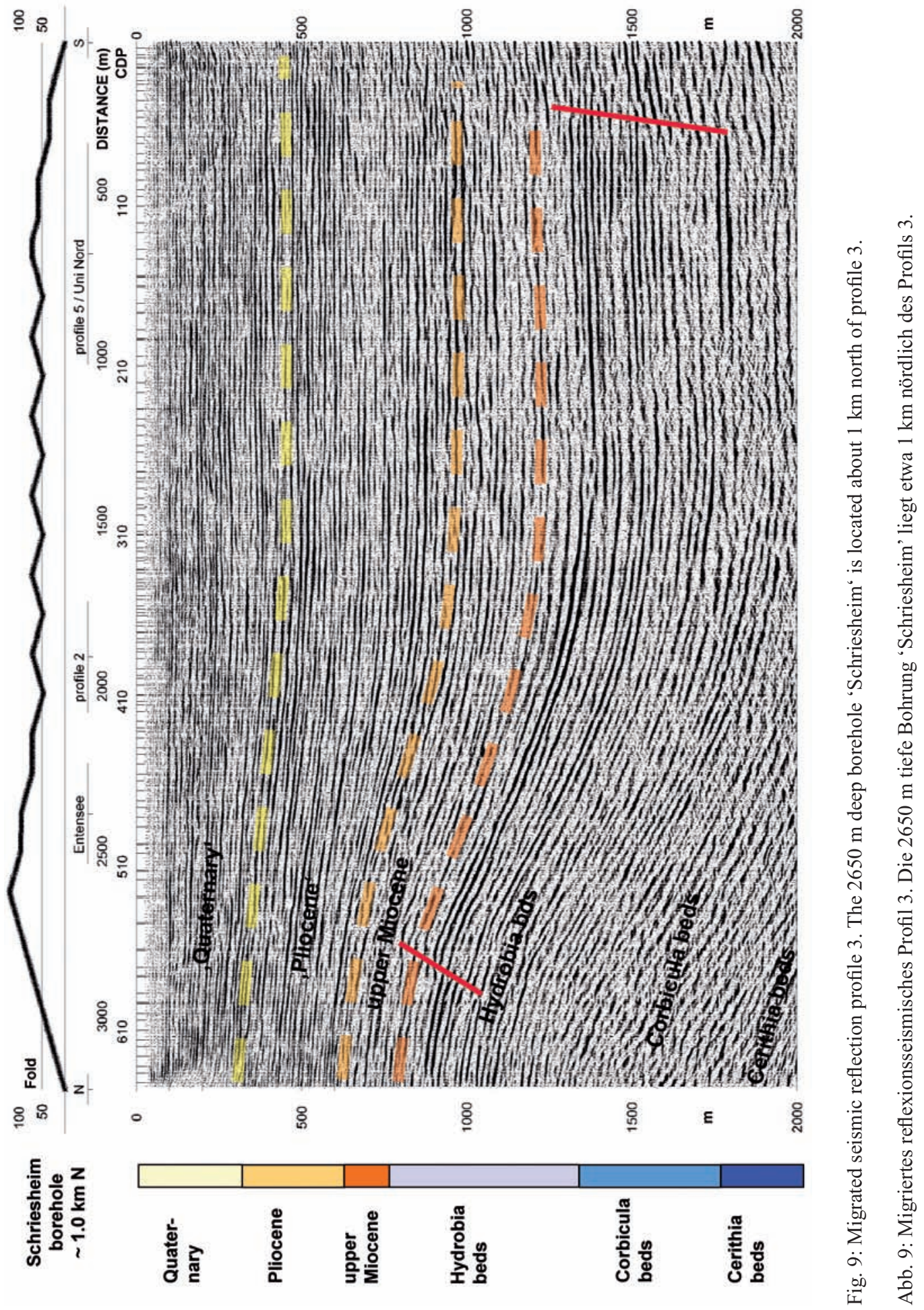




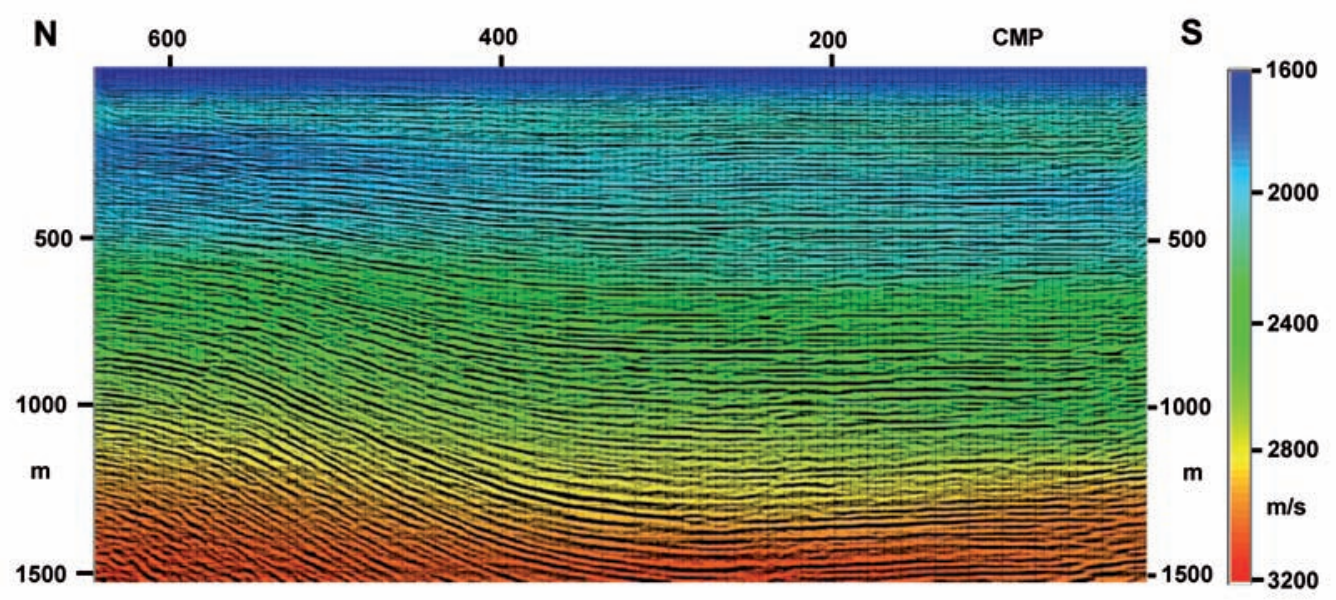

Fig. 10: Estimation of the interval velocity field along reflection profile 3 derived from stacking velocities. The colour-coded interval velocities are overlain by the migrated seismic section shown in Fig. 9.

Abb. 10: Intervallgeschwindigkeiten abgeschätzt aus Stapelgeschwindigkeiten entlang des Profils 3. Die farbkodierten Intervallgeschwindigkeiten sind von dem in Abb. 9 dargestellten migrierten seismischen Profil überlagert.

Fig. 9 shows the preliminary stratigraphical interpretation of profile 3 that considers Base 'Quaternary' and Base Late Miocene. Only based on seismic data, the separation between these units remains ambiguous because of missing continuous reflections, e.g. Base 'Quaternary'. Furthermore, no distinct changes in the reflection patterns mark these boundaries.

Concerning deposits of Quaternary age, segments with strong continuous reflections that reveal correlation lengths in the order of 500 to $1000 \mathrm{~m}$ alternate laterally with sections characterised by low reflection energy and sub-parallel deposition. This can be interpreted in the sense of repeating changes of the depositional environment. At the southern end of the profile, where subsidence was greatest, more continuous reflections become apparent in the deeper part of the Pleistocene than in the north. A throughout, low-reflective, sub-parallel bumpy to chaotic reflection pattern as described by HAIMBERGER, Hoppe \& SCHÄFER (2005) for some parts of the river seismic along the Rhine was not observed in our sections. This gives some evidence for lateral changes of the depositional environments. The reflection patterns caused by the underlying Pliocene and Miocene strata consist of more continuous reflections. Especially in the most southern part of profile 3, some areas at depths between 600 and $700 \mathrm{~m}$ are of low reflectivity. The most distinct reflector appears just below the top of the Hydrobia beds.

The additional subsidence in the 'Heidelberger Loch' - the depocentre of the Heidelberg Basin - amounts to $160 \mathrm{~m}$, with respect to the transition Pliocene / Pleistocene and $300 \mathrm{~m}$ with respect to Base Pliocene. This subsidence is not linked to any faults with large displacements but to flexures of the beds that were probably formed syn-sedimentarily. Faults with distinct displacements are related to the upper strata of the Hydrobia beds only. At the northern end of profile 3, normal faulting is observed. The fault interpreted at the southern end of the profile reveals a pattern that is typical for diffractions although the section is migrated and therefore no diffraction should occur. But this holds only if the fault strikes perpendicular to the seismic profile. Consequently a large fault, proximately south of the profile, is assumed parallel to the course of the Neckar River.

Often, the seismic velocity field images geological structures by sharp vertical and lateral velocity changes. But for the area of the 


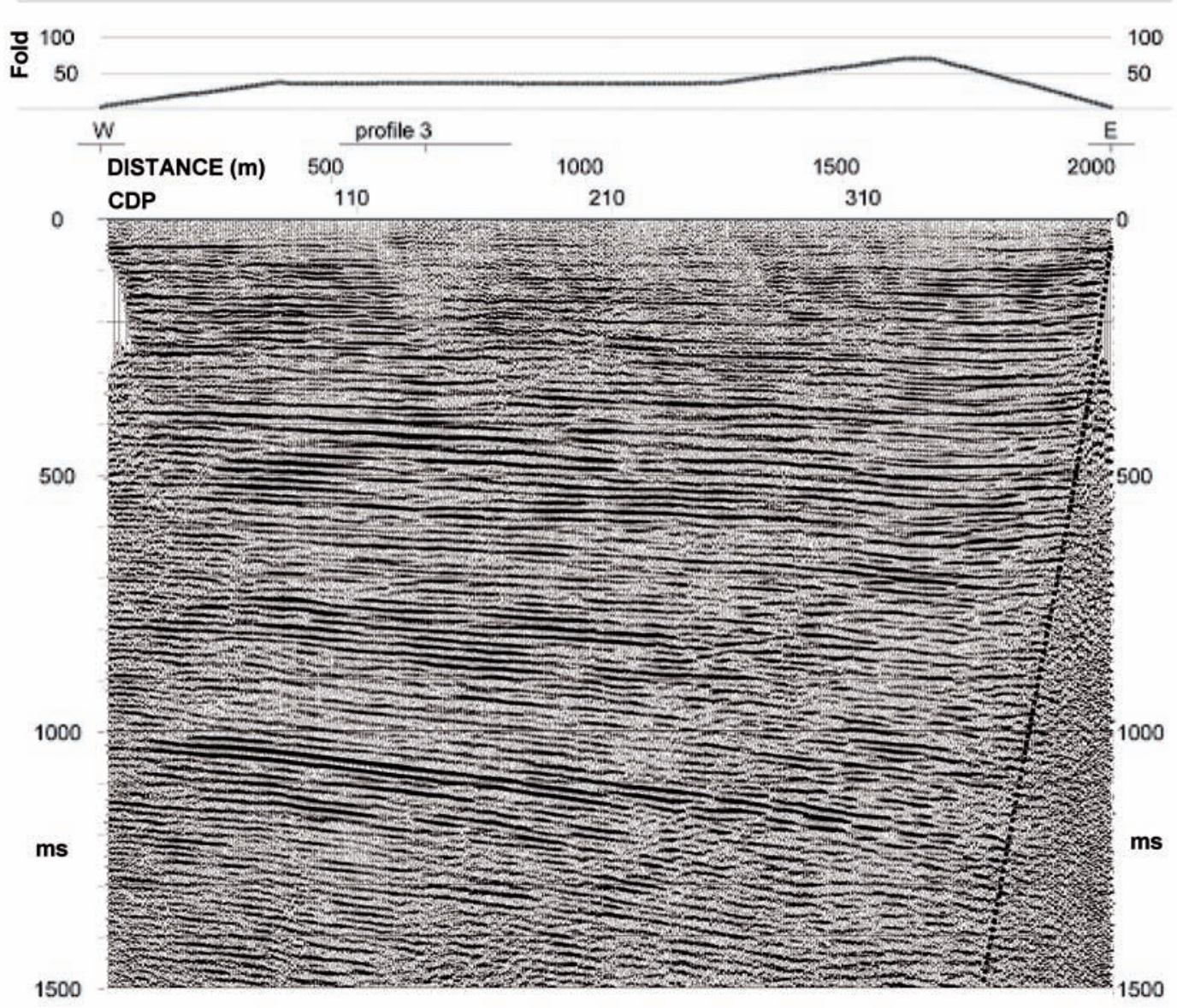

Fig. 11: Stacked seismic reflection profile 2 in time domain, unmigrated. Areas with very low reflectivity in the upper $300 \mathrm{~ms}$ in the central part of the profile are due to strong noise and do not reflect geology. A wedge-shaped zone at the eastern edge of the profile, indicated by a dotted line, maybe caused by the transition of the sedimentary infill of the URG to the crystalline basement of the Odenwald.

Abb. 11: Gestapeltes reflexionsseismisches Profil 2 im Zeitbereich, unmigriert. Die stellenweise sehr geringe Reflektivität in den oberen $300 \mathrm{~ms}$ in zentralen Teil des Profils wird nicht durch die Geologie, sondern durch starke Störungen hervorgerufen. Eine keilförmige, durch eine punktierte Linie markierte Zone am Ostrand des Profils kann durch den Übergang von der Sedimentfüllung der ORG zum kristallinen Grundgebirge des Odenwaldes verursacht werden.

Heidelberg Basin investigated with the new reflection lines no distinct information is provided by the velocity fields. An estimation of the velocity field of profile 3 (Fig. 10) reveals interval velocities that increase gradually from $1600 \mathrm{~m} / \mathrm{s}$ near the surface to $3200 \mathrm{~m} / \mathrm{s}$ at a depth of $1500 \mathrm{~m}$. These velocities are deduced from stacking velocities, which do not constitute physical seismic velocities, since they are affected by layer dips, side reflections, diffractions and other seismic particularities. The reliability of stacking velocities decreases strongly with depth, depending on the maximum offset of the seismic survey. The velocities cannot be controlled by other methods, e.g. VSP measurement, due to the lack of deep VSP (vertical seismic profile) or sonic measurements. However, they coincide 


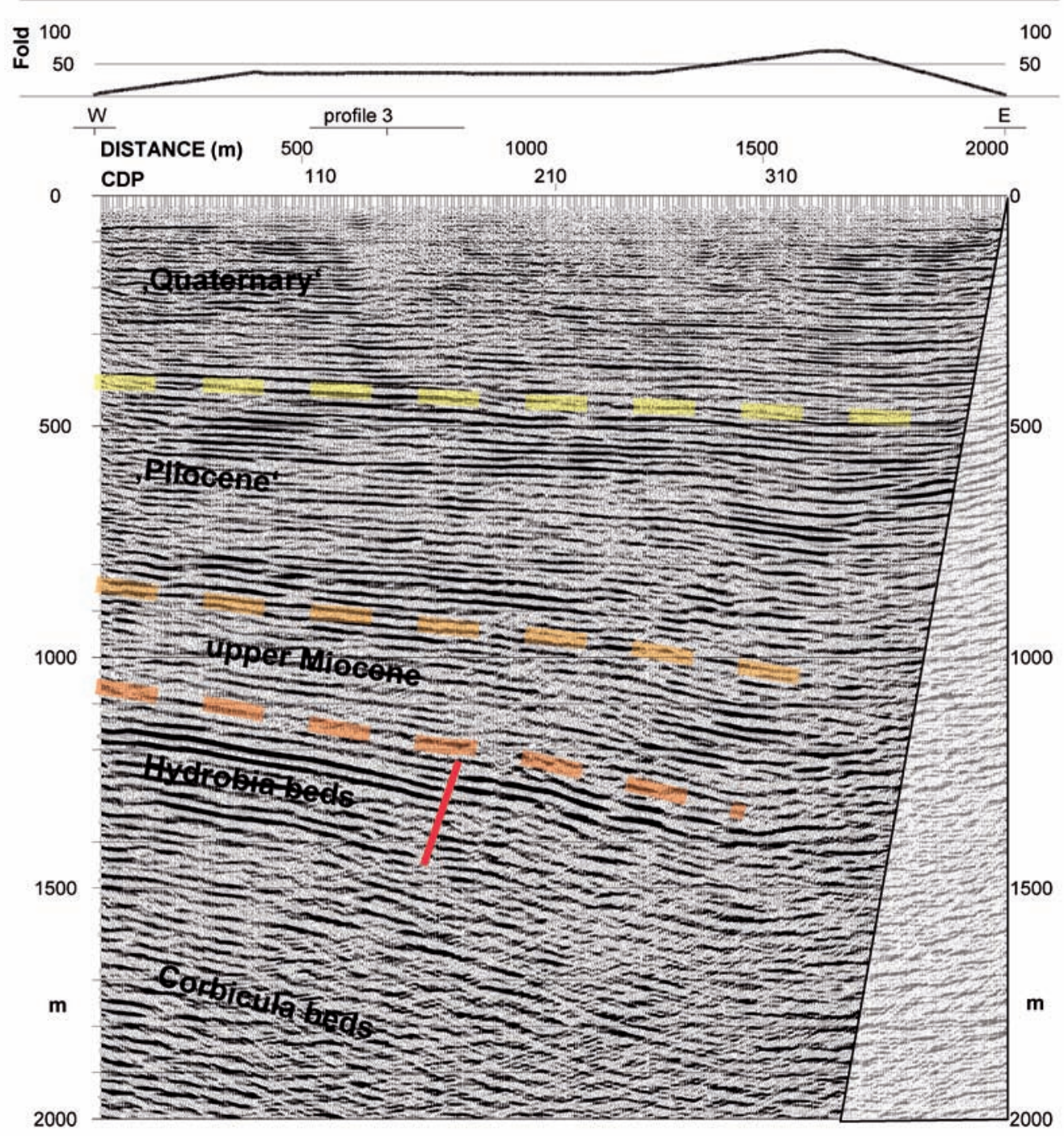

Fig. 12: Migrated seismic reflection profile 2. Seismic signals inside the transparent triangle are not interpretable because of geometrical reasons and migration artefacts. The strongly-bent reflectors close to the triangle zone maybe caused by drag folding.

Abb 12: Migriertes reflexionsseismisches Profil 2. Seismische Signale innerhalb des transparenten Dreiecks können aufgrund der geometrischen Verhältnisse sowie von Migrationsartefakten nicht interpretiert werden. Die stark gekrümmten Reflektoren unmittelbar neben diesem Dreieck könnten auf eine Schleppfalte deuten.

quite well with the regional velocity trend derived from deep boreholes in the Heidelberg Basin. A remarkable feature is a zone of low velocity, which has a depth of approximately $180-250 \mathrm{~m}$ at the northern edge of the profile and of $300-450 \mathrm{~m}$ at its southern edge. The upper limit of this zone corresponds therefore well with the lower boundary of the coarsegrained Weinheim beds (cf. Fig. 3).

Profile 2 is located between the Neckar River and the eastern boundary fault of the Upper Rhine Graben (see Fig. 7). The profile approaches at its eastern edge the topographic border of the URG and hence the master boundary fault of the URG. 
Both the unmigrated time section (Fig. 11) and the migrated depth section (Fig. 12) are presented, so the reader can better judge the influence of the migration processing step. Generally, the reflections dip to the east, with dips becoming greater with increasing depth. A wedge-shaped zone at the easternmost position (marked by the dotted line in Fig. 11) shows no coherent signal. This wedge is probably due to the eastern master fault which juxtaposes the sedimentary infill of the URG against the crystalline basement of the Odenwald. A very rough estimation of its dip yields values of approximately $80^{\circ}$. Adjacent to this wedge, flat or slightly westward dipping reflectors are displayed at travel times greater $700 \mathrm{~ms}$. This feature is interpreted as a drag fold. Below $700 \mathrm{~ms}$, reflections again dip towards east. Some hints for diffractions can be seen, that could be caused by the fault zone (e.g. CMP 260 at $800 \mathrm{~ms}$ ). Areas of apparently low reflectivity as observed in the youngest Quaternary, e.g. between CMP 110 and CMP 310, are caused by strong noise due to pipe waves.

After migration (Fig. 12), the bending of the sediment strata next to the assumed boundary fault becomes more obvious. However, it is difficult to separate real reflections from migration artefacts that always occur at the ends of a seismic profile. Signals inside the marked triangle should not be considered as real reflectors. The continuous subsidence of sediments beneath the central and western part of the profile is revealed by an increasing dip angle with depth. The apparent dip of Base 'Quaternary' is $1.5^{\circ}$ towards east and $4.5^{\circ}$ for Base Pliocene. A fault with a distinct displacement is again only visible in the upper part of the Hydrobia beds. Profile 5 was recorded with modified acquisition parameters (smaller CMP spacing, smaller offset, cp. Table 2), which yielded a higher resolution (Fig. 13). Again, in the eastern part the image of Quaternary deposits is significantly affected by pipe waves. At depths between 600 and $700 \mathrm{~m}$, reduced reflectivity is observed at the western end of the profile. The dip angles of Base 'Quaternary' and Base Pliocene, $2^{\circ}$ and $6^{\circ}$ respectively, are slightly increased with respect to those of profile 2 .

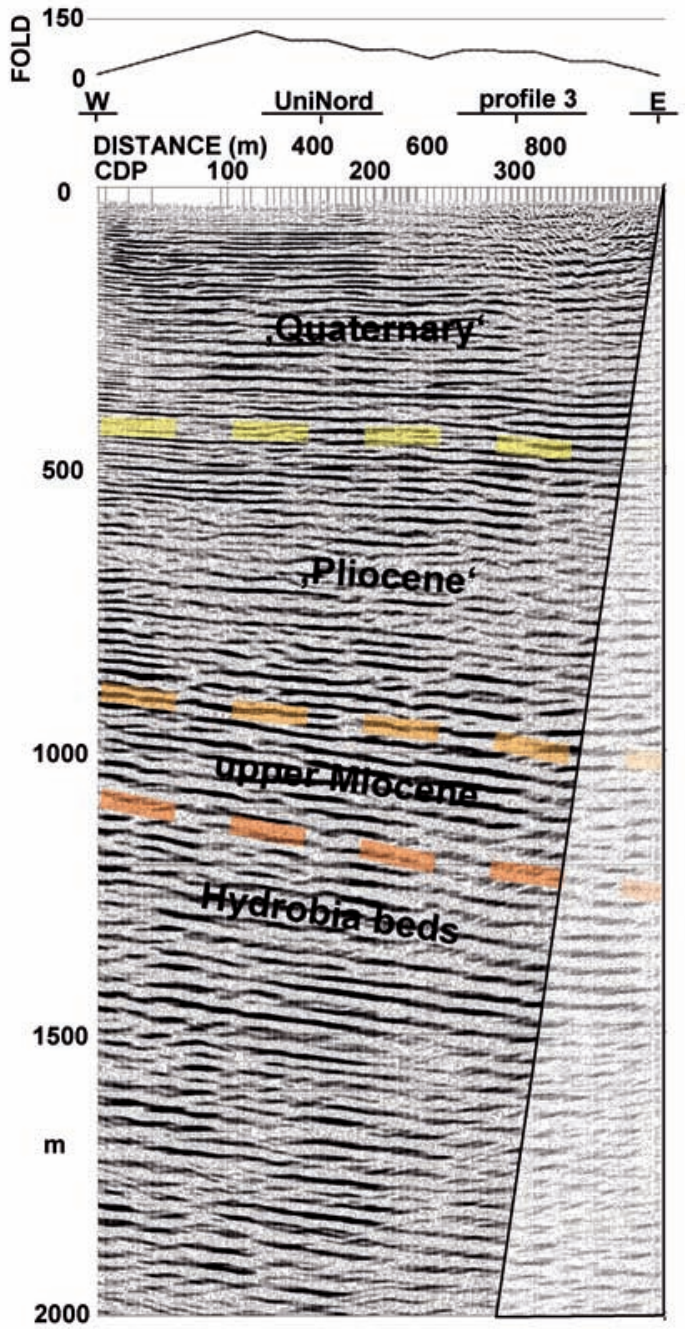

Fig. 13: Migrated seismic reflection profile 5. No seismic information is available inside the transparent triangle for geometric reasons.

Abb. 13: Migriertes reflexionsseismisches Profil 5. Aufgrund der geometrischen Verhältnisse sind innerhalb des transparenten Dreiecks keine seismischen Informationen verfügbar.

In the 'Heidelberg UniNord 1' borehole in 2006 (ELLWANGER et al. 2008), a vertical seismic profile (VSP) was recorded (Fig. 14), as well as numerous other geophysical logging methods (Hunze \& WoniK 2008). To ensure comparability with the reflection seismic profiles, the same vibrator and the same field parameters 


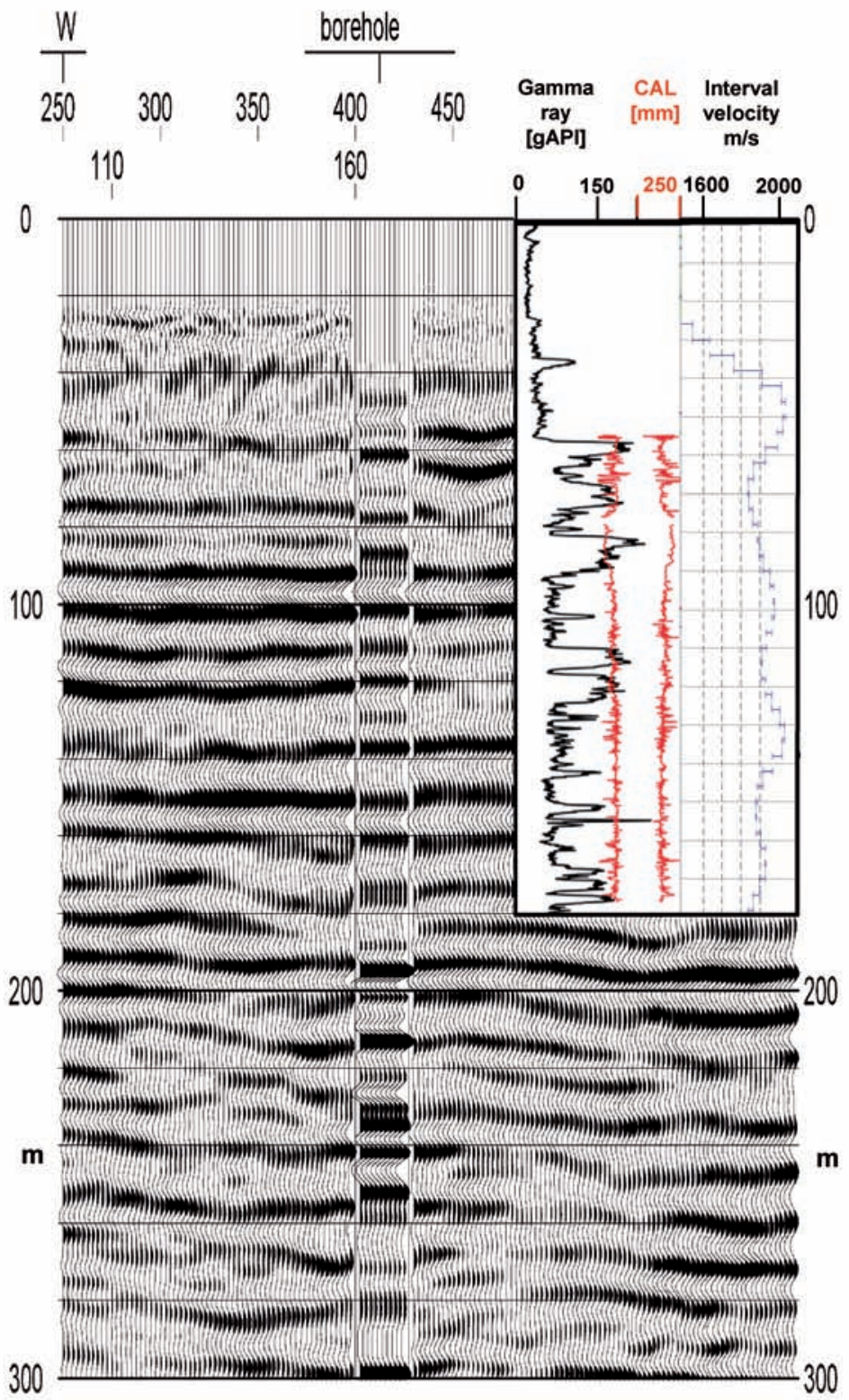

Fig. 14: Detail of seismic profile 5 (cf. Fig. 13) with corridor stack of the VSP (borehole location UniNord 1) inserted. Upper right: gamma ray log, calliper log (after HUNZE \& WonIK 2008), and interval velocities deduced from the VSP. Reference level is surface level at the borehole location $(107 \mathrm{~m})$. Depth conversion is based on VSP-derived velocities down to $180 \mathrm{~m}$ depth.

Abb. 14: Ausschnitt aus dem seismischen Profil 5 (vgl. Abb. 13) mit dem Korridor Stack des VSPs (Bohrlokation UniNord 1). Oben rechts: Gamma Log (nach Hunze \& WonIK 2008), Bohrlochdurchmesser sowie die aus dem VSP abgeleiteten Intervallgeschwindigkeiten. Bezugsniveau ist die Ansatzhöhe des Bohrpunktes $(107 \mathrm{~m})$. Die Tiefenkonvertierung basiert auf den aus dem VSP bis $180 \mathrm{~m}$ Tiefe abgeleiteten Geschwindigkeiten. 


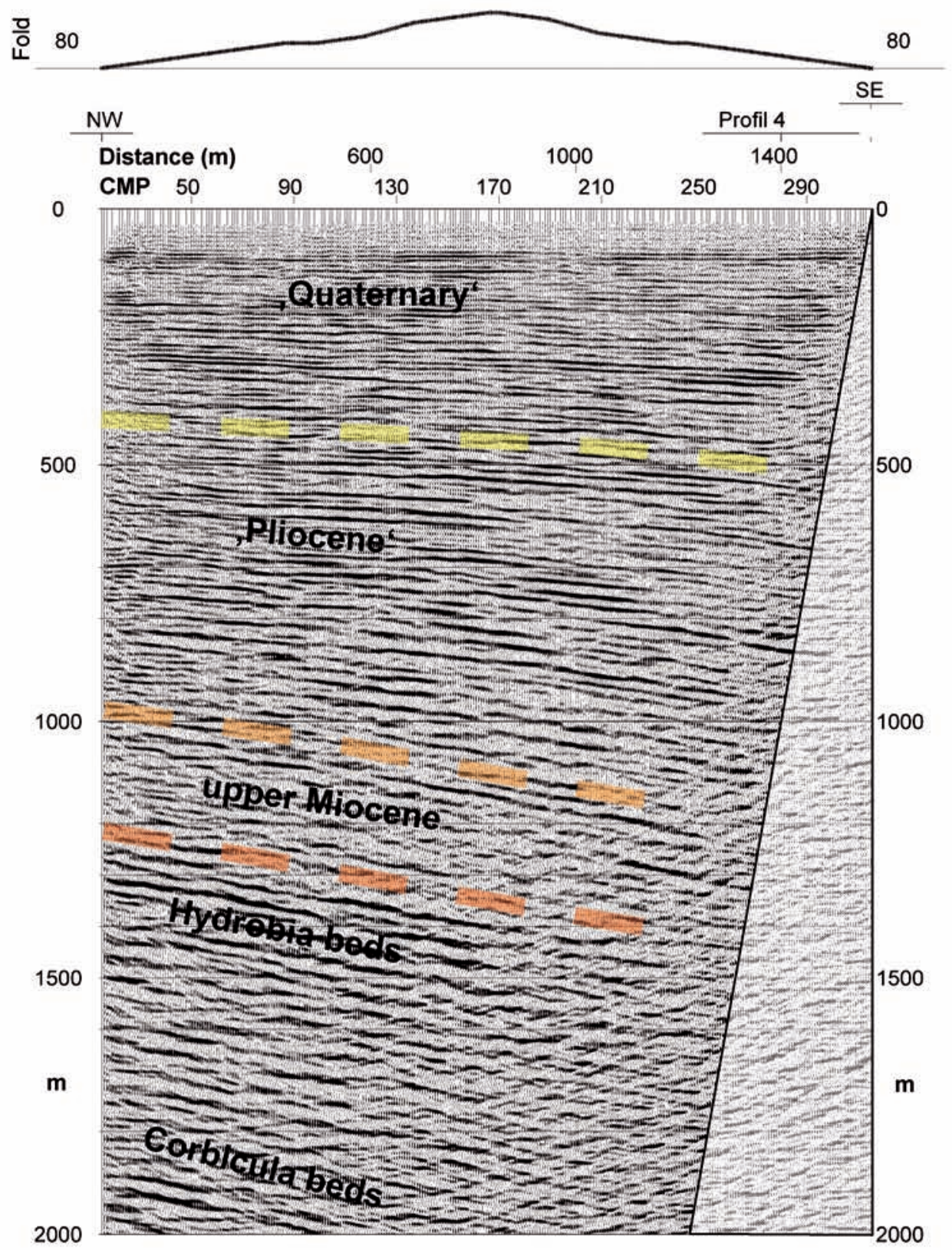

Fig. 15: Migrated seismic reflection profile 1. No seismic information is available inside the transparent triangle for geometric reasons. The strongly northwest-dipping reflectors close to the triangle zone are probably artefacts caused by migration.

Abb. 15: Migriertes reflexionsseismisches Profil 1. Aufgrund der geometrischen Verhältnisse sind innerhalb des transparenten Dreiecks keine seismischen Informationen verfügbar. Die stark nach Nordwesten einfallenden Reflektoren unmittelbar neben diesem Dreieck stellen wahrscheinlich durch die Migration verursachte Artefakte dar. 
were used (Table 2). A depth interval from $180 \mathrm{~m}$ to $32 \mathrm{~m}$ could be measured with a recording distance of $4 \mathrm{~m}$. Several surveys were dependant on the accessible openhole interval. Signal quality is very good and allows an unequivocal determination of traveltimes and the locally-reflected wavefield.

Interval velocities vary between $1850 \mathrm{~m} / \mathrm{s}$ and $2250 \mathrm{~m} / \mathrm{s}$, beside a zone of lower velocity near the surface. A correlation can be observed between the seismic velocity and other petrophysical parameters: low values of the gamma ray $\log$ (coarse-clastic material) correlate with high velocities and high values of the gamma ray log (fine-clastic material) with low velocities. The VSP-derived velocities resemble very closely the smoothed stacking velocities derived from profile 5.

The VSP corridor stack represents the locally-reflected wavefield and corresponds with the surface reflection profiling results. Small discrepancies, as seen in Fig. 14, can be explained by different field geometries and recorded frequencies. The corridor stack was used to calibrate the total static of the reflection seismic lines, since the depths of its reflections are determined directly.

\section{Heidelberg - the region south of the Neckar River}

The new reflection seismic profiles 1 and 4 (Figs. 15, 16) are located south of the Neckar River (see Fig. 7). Therefore a tie to existing deep wells is hardly possible. The observed reflection patterns cannot be easily correlated with those of the hydrocarbon seismic lines, as assumed prior to the surveys. Therefore, the information from the Schriesheim well was correlated along several seismic lines and transferred to the nearest seismic profile recorded by the hydrocarbon industry, which is about $1,5 \mathrm{~km}$ south of profile 4 . But the interpretation of the youngest sediments, e.g. Quaternary, remains especially uncertain, because these were not imaged well in the industrial seismic lines. Both profiles 1 and 4 intersect each other at an angle of about $50^{\circ}$. Again, on both profiles the apparent dip of the sediment fill increases with depth. For Base 'Quaternary' it amounts to $3^{\circ}$, for Base Pliocene it amounts to $9^{\circ}$ (profile 1) and $11^{\circ}$ (profile 4). Therefore, real dip is about $4^{\circ}$ for the Base 'Quaternary' and $11^{\circ}$ for the Base Pliocene, in each case towards east. This is about twice as much as these beds north of the Neckar River have.

Similar to profile 3, Quaternary deposits show quasi-continuous reflections (e.g. profile 1 in $300 \mathrm{~m}$ depth), alternating with weak and partly sub-parallel reflections. Within the Hydrobia beds again a strong reflector occurs that is also visible on the other seismic sections.

\section{Viernheim}

In contrast to the seismic profiles recorded in the Heidelberg area the seismic lines recorded in the vicinity of the Viernheim borehole (Figs. $17,18)$ allow a distinct classification of the sediment fill. Tops of zones of high reflectivity are visible at both depths of $220 \mathrm{~m}$ and $570 \mathrm{~m}$, whereas especially the depth interval between $450 \mathrm{~m}$ and $570 \mathrm{~m}$ shows low reflectivity.

Considering the results of the research borehole Viernheim (HoselmanN 2008) the reflector at a depth of $228 \mathrm{~m}$ can be assigned to the transition between the 'Quaternary' and the underlying material of local provenance (reference height of the seismic line is $100 \mathrm{~m}$ above sea level, the drilling site is $97 \mathrm{~m}$ above sea level). The limnic-fluviatile deposits of local provenance cause the observed high reflectivity.

Due to the high quality of the Viernheim data a complex fault pattern can be identified. Especially on the E-W oriented profile 6 (Fig. 17), a fault zone is observed that runs through all prominent reflection horizons and penetrates deep into the Rhenish facies, e.g. into 'Pleistocene' sediments. Originally a drilling location close to the intersection of profiles 6 and 7 was favoured. Based on these seismic results it was shifted by about $500 \mathrm{~m}$ towards south where the sediment succession was expected to be less affected by faults.

Due to the acquisition parameters and the processing of the seismic data, reflectors above 


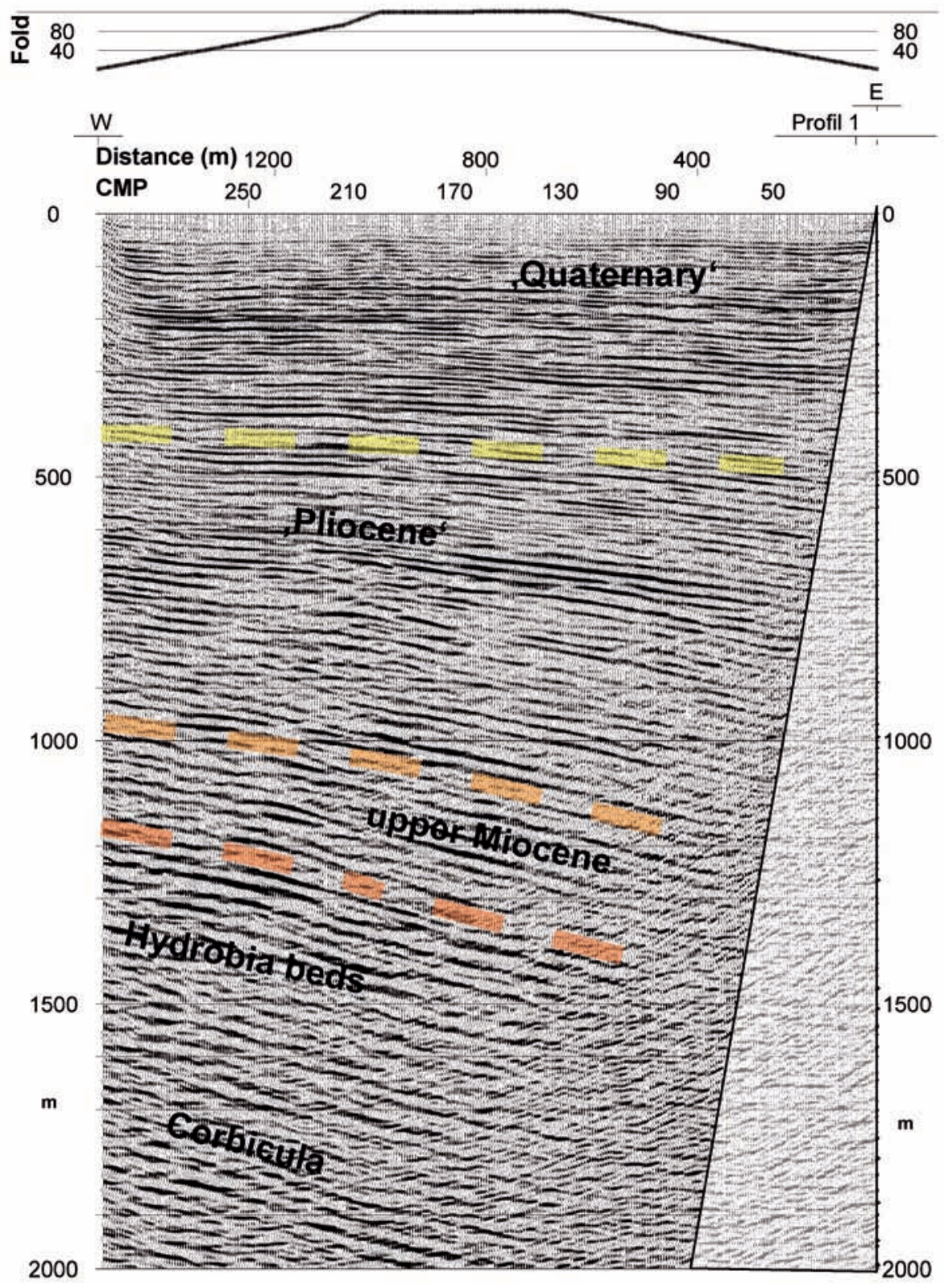

Fig. 16: Migrated seismic reflection profile 4. No seismic information is available inside the transparent triangle for geometric reasons. The strongly west-dipping reflectors close to the triangle zone are probably artefacts caused by migration.

Abb. 16: Migriertes reflexionsseismisches Profil 4. Aufgrund der geometrischen Verhältnisse sind innerhalb des transparenten Dreiecks sind keine seismischen Informationen verfügbar. Die stark nach Westen einfallenden Reflektoren unmittelbar neben diesem Dreieck stellen wahrscheinlich durch die Migration verursachte Artefakte dar. 


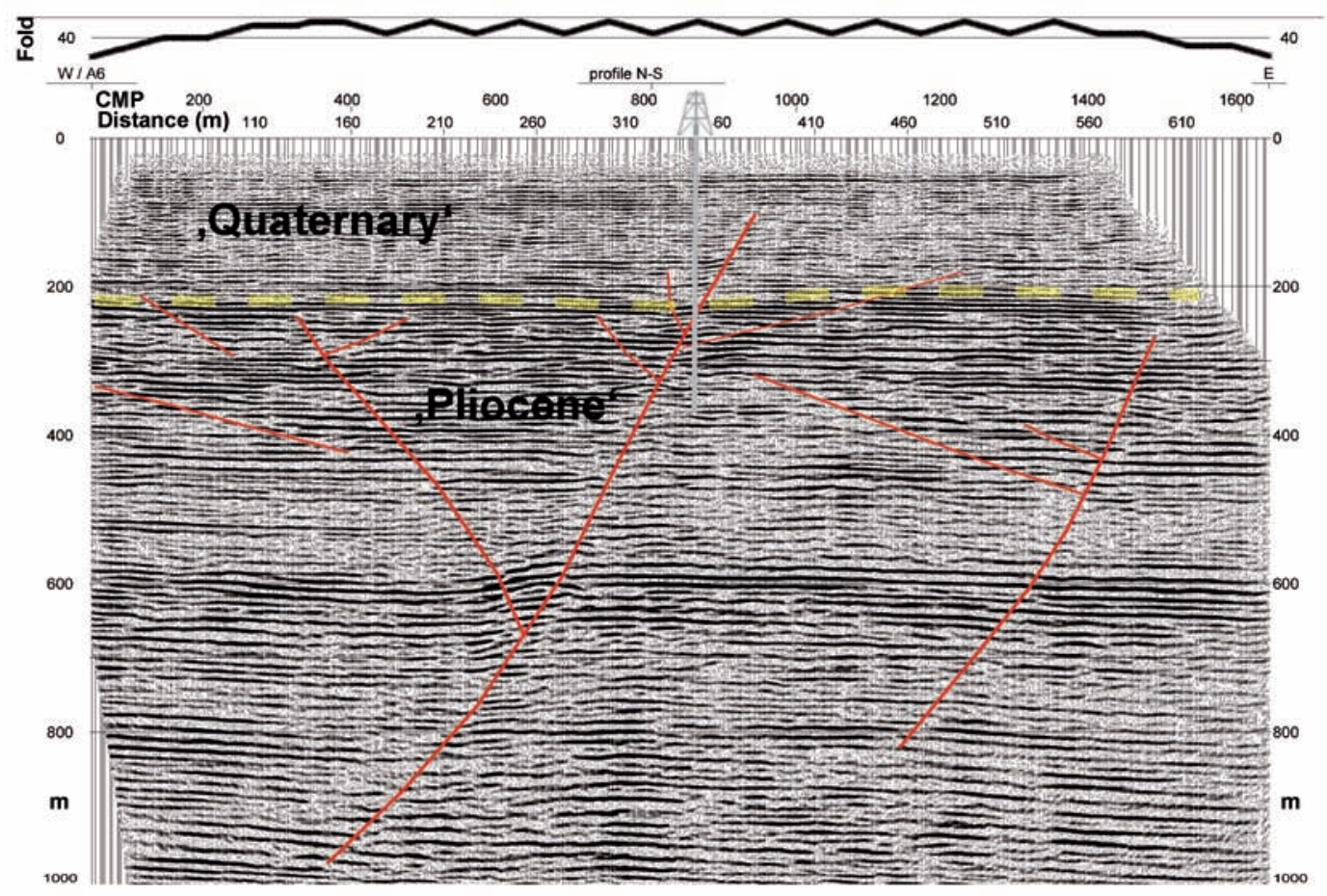

Fig. 17: Migrated seismic reflection profile 6 near Viernheim. The initially-proposed borehole location (marked by a derrick) was abandoned after the seismic became available to avoid the predicted faults. The location was than shifted about $500 \mathrm{~m}$ to the south (see Fig. 18).

Abb. 17: Migriertes reflexionsseismisches Profil 6 bei Viernheim. Der ursprünglich vorgeschlagene Bohrpunkt (Bohrturm) wurde aufgegeben, nachdem die Seismik verfügbar war, um ein Durchbohren der prognostizierten Störungen zu vermeiden. Der Bohrpunkt wurde sodann ungefähr 500 m nach Süden verschoben (vgl. Abb. 18).

$35 \mathrm{~m}$ depth cannot be mapped. The first strong reflection that can be correlated along the entire profile is imaged at $40 \mathrm{~m}$ depth, two more are found at $80 \mathrm{~m}$ and $180 \mathrm{~m}$ depth. The uppermost two reflectors are most probably related to the top and the base of the Ladenburg Horizon, a prominent fine-grained horizon in the Upper Rhine Graben (in hydrostratigraphy named the 'Oberer Zwischenhorizont').

A precise and detailed stratigraphic interpretation of the reflectors below $570 \mathrm{~m}$ depth was not possible, because these were not reached by the research borehole. Instead we intend to achieve this by using industrial reflection seismic data, which is much denser than in the Heidelberg area.

\section{Discussion and Conclusion}

For the Heidelberg Basin thick sediment sequences are apparent, both in gravity and seismic data. Quantitative interpretation remain preliminary, as long as no deep boreholes can be included and 3-D models based on gravimetric and seismic data can be calculated, that additionally consider data from the hydrocarbon industry.

The seismic data at the locations of Viernheim and Heidelberg show quite different images, indicating varying sedimentological processes throughout the Heidelberg Basin. Confirming this, seismic measurements along the Rhine River (Haimberger, Hoppe \& Schäfer 2005, BERTRAND et al. 2006) show yet other seismic 


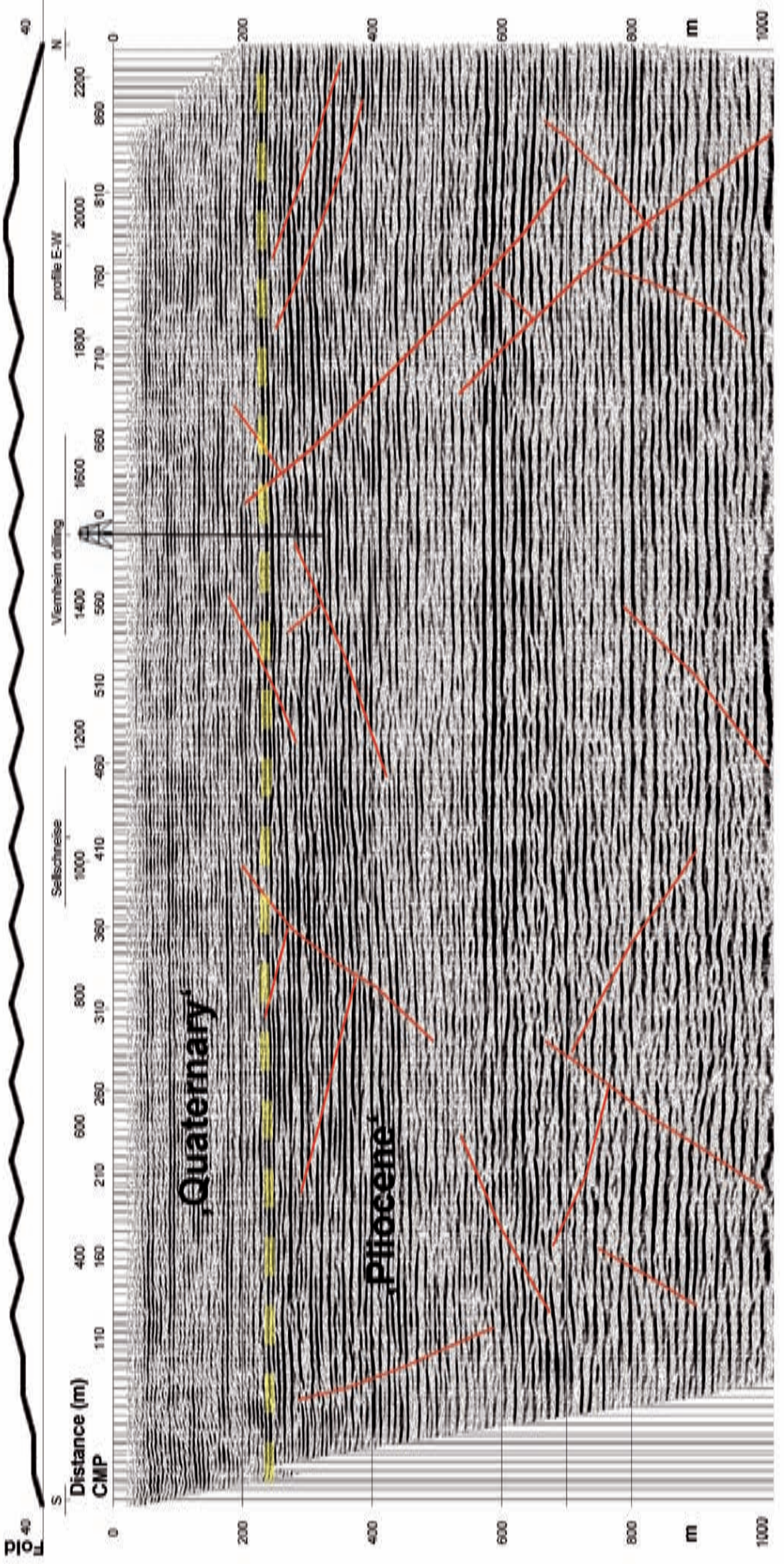

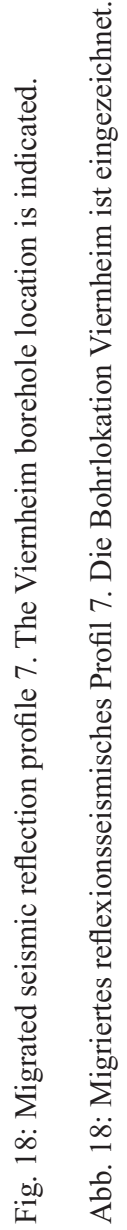


characteristics. Therefore a consistent seismic stratigraphy for the Plio-/Pleistocene sediments of the URG is not achievable within the limits of the presently applied inconsistent stratigraphic scenarios.

Concerning the location of the Viernheim boreholes, two new reflection seismic profiles image a sedimentary environment that is affected by tectonics, as documented by several faults. But these faults are mainly restricted to older sediments, e.g. to depths greater than about $225 \mathrm{~m}$ (Pliocene and older according to Hoselmann 2008). In contrast, during the Quaternary the tectonic activity seems to be quiet. Along the entire profile these sediments are horizontal. But on a smaller scale much more detailed information is imaged by the two seismic lines indicating a complex depositional system, especially during Pliocene or even older times. Considering the results of the Viernheim research borehole, the top and the base of a finegrained horizon, comprising the Ladenburg Horizon (Oberer Zwischenhorizont) at about 40 and $80 \mathrm{~m}$, respectively, depths can be traced in the seismic section. Reflections at a depth of about $180 \mathrm{~m}$ can be correlated with a sequence of regional distributed fine-grained sediments (Unterer Zwischenhorizont).

The top of the uppermost section of high reflectivity can be correlated with the transition from the Rhenish facies (alpine) sediments to material with local provenance at a depth of $225 \mathrm{~m}$, as revealed by heavy mineral analysis, carbonate content, and petrography (HoselmanN 2008). Whether this seismic reflector can be interpreted as the transition Plio-/Pleistocene must be investigated by additional palynological studies that are not yet available.

The most important result derived from the seismic pre-site survey at the Heidelberg UniNord location is the existence of a subbasin in the Heidelberg Basin close to the eastern margin of the Upper Rhine Graben. The additional subsidence adds up to some hundred meters with respect to deeper strata, as imaged on profile 3, e.g. about $400 \mathrm{~m}$ for the top of the Hydrobia beds. All recorded profiles do not show any disconformities, faults are restricted to early Miocene (Hydrobia beds or older) units. However, this observation does not exclude potential hiatuses, which cannot be imaged by reflection seismic data.

By tying the new reflection lines to the Schriesheim well, the transition Pliocene to Pleistocene was predicted at depths between 400 and $500 \mathrm{~m}$. This statement was based on the assumption that the extrapolation of information of the industry seismic lines across the gap between the northern end of the seismic profile 3 and the location of the Schriesheim borehole is correct. Furthermore using the interpretation of Base 'Quaternary' from a hydrocarbon well is uncertain because information is not available on the kind of data it is based on. Work done in the framework of hydrocarbon exploration was focused on deep structures rather than on young sediments.

The seismic lines reveal more or less continuous subsidence. The dip of sediments towards east increases with depth, showing a classical rollover anticline structure at the eastern URG master fault. The amount of subsidence increases from north to south: the Base Pliocene dips east by about $4.5 \%$ on profile 2 , $6 \%$ on profile 5 and $11 \%$ on profile 1 and 4 . These values make a major fault zone beneath the Neckar River plausible, of which indications can be found at the southern end of profile 3. Differential compaction may have played a role by increasing the dip of the Miocene and younger strata. The rollover structure is not found to the north, as well as to the south of the 'Heidelberger Loch', as inferred from industry seismic profiles, which affirms it as the area with the most rapid subsidence.

Due to the thick sequences of Plio-/Pleistocene sediments, the research boreholes Heidelberg UniNord reveals a unique high temporal resolution. From the first Heidelberg borehole in 2006 a time marker of the Waalian stage is reported at $183 \mathrm{~m}-210 \mathrm{~m}$ depth (HAHNE, EllWANGER \& STRITZKe 2008). As the age of the Waalian is considered to amount to $1.5 \mathrm{Ma}$, and assuming continuous sedimentation, the Top of the Pliocene at $2.6 \mathrm{Ma}$ has to be expected at only $365 \mathrm{~m}$ depth. However, the preliminary interpretation of the new reflection seismic 
profiles reveals Base 'Quaternary' first at about $430 \mathrm{~m}$ depth. Consequently, concerning the early Quaternary, increased sedimentation rates can be expected.

To aim on a deeper understanding of the basin genesis, a crucial point in the chronostratigraphic interpretation of seismic reflectors will be the proper definition of 'Base Quaternary'. A major step is also expected once the new drillings will be interpreted and correlated using the tools of sequence stratigraphy (ELLWANGER et al. 2008). We are convinced that this will also include a consistent seismic scenario.

\section{Acknowledgement}

The seismic surveys in Viernheim and Heidelberg were performed by our colleagues Stefan Cramm, Günther Druivenga, Siegfried Grüneberg, Eckhardt Großmann, Walter Rode, Detlef Vogel, and Wolfgang Weitmüller. VSP measurements were part of the geophysical logging program and conducted by Thomas Grelle and Ferdinand Hölscher. Site-specific logistic support was given by Stadtwerke Heidelberg and Abwasserzweckverband Heidelberg. All this is gratefully acknowledged. Thanks also to our colleagues from the geological surveys, Ulrike Wielandt-Schuster, Christian Hoselmann, and Michael Weidenfeller, for cooperation and permanent discussion in this drilling project. An anonymous reviewer is thanked for his critical review, David Tanner for linguistic assistance.

\section{References}

Bartz, J. (1951): Revision des Bohr-Profils der Heidelberger Radium-Sol-Therme. - Jahresbericht und Mitteilungen des Oberrheinischen Geologischen Vereins, 33: 101-125.

BARTZ, J. (1974): Die Mächtigkeit des Quartärs im Oberrheingraben. - In: J.H. ILLIES \& K. FuCHS (eds.): Approaches to Taphrogenesis, InterUnion Commission on Geodynamics, Scientific report No. 8: 78-87; Stuttgart (Schweizerbart).

Bartz, J. (1982), mit Beitr. von Brelie, G. von der und Maus, H.: Quartär und Jungtertiär II im Oberrheingraben im Großraum Karlsruhe. - Geologisches Jahrbuch, A 63: 3-237.
Bertrand, G., Elsass, P., Wirsing, G. \& Luz, A. (2006): Quaternary faulting in the Upper Rhine Graben revealed by high resolution multi-channel reflection seismic. - Comptes Rendus Géosciences, 338: 574-580.

Brun, J. P. \& Gutscher, M. A. (1992): Deep crustal structure of the Rhine Graben from DEKORPECORS seismic reflection data: a summary. - Tectonophysics, 208/1-3: 139-147.

BunEss, H. \& Wiederhold, H. (1999): Experiences with a Vibrator System for Shallow High-Resolution Seismics. - 61st EAGE Conference \& Technical Exhibition, Extented Abstracts Vol. 1: 4-42.

Closs, H. (1943): Gravimetrische Überlegungen zum geologischen Profil der Thermalbohrung von Heidelberg. - Oel und Kohle in Gem. mit Brennstoff-Chemie, 43/44: 942-951.

Conrads, H. \& Schneider, E. (1977): Hydrogeologische und brunnentechnische Probleme bei der Wassererschließung aus dem tiefen Pleistozän des Oberrheintalgrabens für die Stadtwerke Heidelberg AG. - Brunnenbau, Bau von Wasserwerken, Rohrleitungsbau, Heft 1: 5-10.

Derer, C. (2003): Tectono-sedimentary evolution of the Northern Upper Rhine Graben (Germany), with special regard to the early syn-rift stage. - PhD Thesis, University Bonn; Bonn: 99 p.

Derer, C., Schumacher, M. \& Schäfer, A. (2005): The northern Upper Rhine Graben: basin geometry and early syn-rift tectono-sedimentary evolution. - International Journal of Earth Sciences, 94: 640-656.

Derer, C., Kosinowski, M., Luterbacher, H., SCHÄFER, A. \& Süß, M.P. (2003): Sedimenary response to tectonics in extensional basins: the Pechelbronn Beds (Late Eocene to Early Oligocene) in the northern Upper Rhine Graben, Germany. - In: McCAnN, T. \& SaIntot, A. (eds.): Tracing tectonic deformation using the sedimentary record. - Geological Society, special publication, 208: 55-69.

Doebl, F. \& Olbrecht, W. (1974): An isobath map of the Tertiary base in the Rhinegraben. - In: J.H. Illies \& K. Fuchs (eds.): Approaches to Taphrogenesis, Inter-Union Commission on Geodynamics, Scientific report No. 8: 71-72; Stuttgart (Schweizerbart).

Ellwanger, D., Gabriel, G., Hoselmann, C., Lämmermann-Barthel, J. \& Weidenfeller, M. (2005): The Heidelberg Drilling Project (Upper Rhine Graben, Germany). - Quaternaire 16/3: 191-199. 
Ellwanger, D., Gabriel, G., Simon, T., WielandtSChuster, U., Greiling, R.O., Hagedorn, E.-M., Hahne, J. \& Heinz, J. (2008): Long sequence of Quaternary Rocks in the Heidelberg Basin Depocentre. - Quaternary Science Journal (Eiszeitalter und Gegenwart), 57/3-4: 316-337.

Fezer, F. (1997): 220 m Altpleistozän im ,Heidelberger Loch'. - Eiszeitalter und Gegenwart, 47: 145-153.

Hahne, J., Ellwanger, D. \& Stritzke, R. (2008): Evidence for a Waalian thermomer pollen record from the research borehole Heidelberg UniNord Upper Rhine Graben, BadenWürttemberg. - Quaternary Science Journal (Eiszeitalter und Gegenwart), 57/3-4: 403-410.

Haimberger, R., Hoppe, A. \& Schäfer, A. (2005): High-resolution seismic survey on the Rhine River in the northern Upper Rhine Graben. - In: Behrmann, J.H., Ziegler, P.A., Schmid, S.M., Heck, B. \& Granet, M. (eds.): EUCOR-URGENT Upper Rhine Graben Evolution and Neotectonics. - Special Issue, International Journal of Earth Sciences, 94/ 4: 657-668.

HGK (1999): Hydrogeologische Kartierung und Grundwasserbewirtschaftung Rhein-NeckarRaum. Fortschreibung 1983-1999. - Ministerium für Umwelt und Verkehr Baden-Württemberg, Hessisches Ministerium für Umwelt, Landwirtschaft und Forsten, Ministerium für Umwelt und Forsten Rheinland-Pfalz: 155 p.; Stuttgart, Wiesbaden, Mainz.

Hoselmann, C. (2008): The Pliocene and Pleistocene fluvial evolution in the northern Upper Rhine Graben based on results of the research borehole at Viernheim (Hessen, Germany). - Quaternary Science Journal (Eiszeitalter und Gegenwart), 57/3-4: 286-315.

Hunze, S. \& WoniK, T. (2008): Sediment Input into the Heidelberg Basin as determined from Downhole Logs. - Quaternary Science Journal (Eiszeitalter und Gegenwart), 57/3-4: 367-381.

Mauthe, G., Brink, H.J. \& Burri, P. (1993): Kohlenwasserstoffvorkommen und -potential im deutschen Teil des Oberrheingrabens. - Bulletin der Vereinigung Schweizerischer Petroleum-Geologen und Ingenieure, 60/137: 15-29.
Peters, G. (2007): Active tectonics in the Upper Rhine Graben - Integration of paleoseismology, geomorphology, and geomechanical modelling. - $\mathrm{PhD}$ theses, Vrije Universiteit Amsterdam: $270 \mathrm{p}$.

Rotstein, Y., Edel, J.-B., Gabriel, G., Boulanger, D., Schaming, M. \& Munschy, M. (2006): Insight into the structure of the Upper Rhine Graben and its basement from a new compilation of Bouguer Gravity. - Tectonophysics, 425: 55-70.

SAlomon, W. (1927): Die Erbohrung der Heidelberger Radium-Sol-Therme und ihre geologischen Verhältnisse. - Abhandlungen der Heidelberger Akademie der Wissenschaften, 14. Abhandlung: 104 p.; Berlin, Leipzig (Walter de Gruyter \& Co.).

Schumacher, M.E. (2002): Upper Rhine Graben: Role of pre-existing structures during rifting evolution. - Tectonics, Vol. 21/1: doi:10.1029/ 2001/TC900022.

Symbolschlüssel Geologie Baden-Württemberg. Verzeichnis Geologischer Einheiten - Aktual. Ausg. März 2007. - Internet-Publ.: http:// www.lgrb.uni-freiburg.de; Freiburg i. Br. (Reg.Präs. Freiburg - L.-Amt Geol. Rohst. Bergb.).

VAn der Veen, M., Buness, H.A., BüKer, F. \& Green, A.G. (2000): Field Comparison of High-frequency Seismic Sources for Imaging Shallow (10$250 \mathrm{~m}$ ) Structures. - Journal of Environmental and Engineering Geophysics, 5/2: 39-56.

Weidenfeller, M. \& KärCher, T. (2008): Tectonic influence on fluvial preservation: aspects of the architecture of Middle and Late Pleistocene sediments in the Northern Upper Rhine Graben, Germany. - Netherlands Journal of Geosciences - Geologie en Mijnbouw, 87/1: 33-40.

Weidenfeller, M. \& Knipping, M. (2008): Correlation of Pleistocene sediments from boreholes in the Ludwigshafen area, western Heidelberg Basin. - Quaternary Science Journal (Eiszeitalter und Gegenwart), 57/3-4: 270-385.

YILMAZ, Ö. (2001): Seismic data analysis: processing, inversion and interpretation of seismic data. - In: DoHerTy, S.M. (ed.): Investigations in Geophysics, 10; Tulsa (Society of Exploration Geophysicists): 2024 p. 